\title{
ESPAÇOS LIVRES PÚBLICOS: UTILIZAÇÃO DE INFRAESTRUTURA VERDE PARA OTIMIZAR A DRENAGEM URBANA NOS CENTROS HISTÓRICOS TOMBADOS
}

\author{
PUBLIC OPEN SPACES: UTILIZATION OF GREEN INFRASTRUCTURE TO OPTIMIZE \\ URBAN DRAINAGE IN REGISTERED HISTORIC PROPERTY
}

\author{
Claudione Fernandes de Medeiros* \\ Sonia Afonso**
}

\section{RESUMO}

As mudanças climáticas impactam a vida das cidades. Eventos extremos, como aumento da temperatura, secas e enchentes, ameaçam também o patrimônio cultural. Nos centros históricos tombados, as enxurradas e alagamentos vêm provocando muitas patologias no casario e no arruamento. O sistema de drenagem urbana tradicional tem se mostrado ineficiente e há dificuldades de ampliação dessa rede em face de prerrogativas de respeito às preexistências. Este estudo procura utilizar os espaços livres públicos das cidades tombadas como potencializadores da drenagem urbana por meio dos conceitos de infraestrutura verde. Inicialmente apresenta a relação entre as mudanças climáticas e os transtornos à paisagem cultural e como a infraestrutura verde pode contribuir para a resiliência dos centros urbanos tombados. Após são analisados os sistemas de espaços livres públicos passíveis dessa aplicação, tendo como estudo de caso a cidade de Laguna, no estado de Santa Catarina (SC). Como resultado observou-se que os espaços livres públicos devem transmutar sua função meramente cênica para a função infraestrutural. Dessa forma serão vitais para os centros urbanos, pois, além de valorizar a paisagem, aumentarão a eficácia da drenagem sem impactar ou desconsiderar a geomorfologia e a morfologia urbana existentes.

Palavras-chave: Espaços livres públicos. Infraestrutura verde. Centro histórico tombado.

\section{ABSTRACT}

Climate change affects city life. Extreme events, such as temperature rising, droughts, and floods, also threaten cultural heritage. In historic city centers, floods and heavy rain have caused pathologies in properties and streets. The traditional urban drainage system has shown to be inefficient, in addition to the difficulties of expanding this system due to pre-existing matters. This study seeks to use public open spaces in historic city centers to improve urban drainage, through the concept of green infrastructure. At a first glance, it draws a relation between climate changes, and the disturbances to the cultural landscape, also how a green infrastructure can contribute to a resilience of the historic city centers. Next, the public open spaces system available for this application is analyzed, taking the the city of Laguna, in Santa Catarina, as a case study. As a result, public open spaces should be used as an infrastructural feature instead of being there as mere scenery. Thus, they shall become vital to the urban centers, valuing landscape, and increasing the effect of the drainage, without impacting or disregarding existing geomorphology and urban morphology.

Keywords: Public open spaces. Green infrastructure. Historic city center.

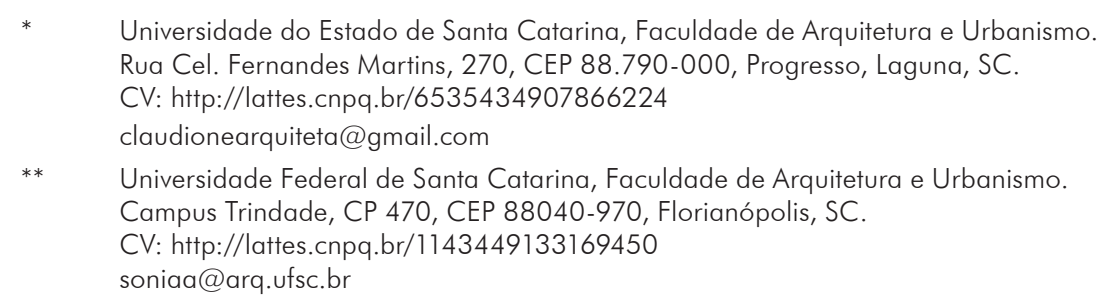




\section{INTRODUÇÃO}

O tema central deste artigo está relacionado com a utilização dos conceitos de infraestrutura verde nos sistemas de espaços livres sob o domínio público para potencializar a drenagem das águas de chuva dos centros históricos tombados, tendo como estudo de caso a cidade de Laguna no estado de Santa Catarina (SC). Seu propósito principal é contribuir para a resiliência do patrimônio nacional. Outros benefícios são atribuídos à utilização de infraestrutura verde, como a valorização paisagística, a criação de microclimas e a diminuição da polvição difusa (HERZOG, 2010).

A cidade é uma construção ao longo do tempo e do espaço, um legado com relevante valor histórico e cultural que deve ser preservado. A dinâmica urbana ocorre de maneira diferente, dependendo dos atores envolvidos no processo, das regras e leis que regem seu planejamento. Concepções sociais, econômicas, ambientais e estéticas se alternam e se completam para escrever sua história. A releitura da história e da cultura do nosso povo deve ser preservada e requalificada para que as cidades não percam sua dinâmica e qualidade, fortalecendo sua identidade cultural.

O Instituto do Patrimônio Histórico e Artístico Nacional (Iphan) promove o tombamento de conjuntos urbanísticos, conferindo-Ihes status de patrimônio nacional. $\bigcirc$ tombamento é um ato administrativo que tem como principal objetivo preservar - por meio de amparo legal - os bens com valores histórico, cultural, arquitetônico e ambiental, impedindo sua destruição ou descaracterização. A preservação dos referenciais de uma sociedade deve possuir dimensões interativas entre espaço e tempo, contemplando e valorando cada época.

As transformações na paisagem cultural e as mudanças climáticas fazem parte de uma série de questões, discutida nos últimos tempos, relacionada às águas urbanas. As cidades precisam adaptar-se para se tornarem resilientes aos impactos ambientais, ou seja, precisam desenvolver a capacidade de voltar à forma e às características originais após passarem por processos que interferem em sua dinâmica. A infraestrutura verde vem sendo aplicada com resultados positivos em várias cidades, principalmente na Europa e na América do Norte, como complemento ou alternativa às estruturas tradicionais de drenagem urbana. No entanto, tal estratégia ainda não foi utilizada nacionalmente para amenizar a drenagem insuficiente dos centros históricos tombados e consolidados. Em respeito a essa condição, os sistemas de espaços livres preexistentes são os dimensionadores dessa aplicação, devendo ser analisados e preparados para tal função - que colabora com a eficiência da drenagem urbana, auxiliando na conservação dos recursos naturais e do patrimônio construído.

A paisagem envolve um conjunto de percepções que vai desde o espaço original primitivo - o território - até as relações culturais e socioeconômicas geradoras de modificações em que o ser humano é um dos agentes transformadores do ambiente. Para Limberger e Santos (2000, p. 1) "[...] a paisagem é um conjunto de cenários naturais ou artificiais onde o homem é, além de um observador, um transformador desses elementos que compõem o sítio". Macedo (1993, p. 11) adota a ideia de paisagem 
como "[...] expressão morfológica das diferentes formas de ocupação e, portanto, de transformação do ambiente em um determinado tempo". A paisagem pode ser entendida como um sistema vivo, com constantes ações e reações, que compõe o tecido de nossa existência (WATERMAN, 2010).

A arquitetura e o urbanismo estão relacionados à paisagem, visto que esta é uma interpretação contínua do edificado e do não edificado. Segundo Magalhães (2001), ela deve ser caracterizada com olhar crítico, buscando o respeito pela ecologia, o trabalho e os conhecimentos adquiridos pelas gerações. Para Ab'Saber:

A paisagem é sempre uma herança. Na verdade, ela é uma herança em todo o sentido da palavra: herança de processos fisiográficos e biológicos, e patrimônio coletivo dos povos que historicamente as herdaram como território de atuação de suas comunidades (AB'SABER, 2003, p. 9).

A forma urbana, constituída por um conjunto de volumes construídos e um sistema de espaços livres, é gerada a partir de agentes naturais do território e intervenções antrópicas. Waterman (2010, p. 15) fala que, "[...] embora demos forma à paisagem, nós, ao mesmo tempo, somos produtos dos lugares". A partir dessa concepção, a paisagem deixa de ser mero fenômeno físico e passa a ser a produção cultural de um povo. Quando tratada como bem patrimonial, agregando diversos valores, recebe a qualificação de paisagem cultural. Ribeiro (2007) preconiza a vantagem desse termo no seu caráter relacional e integrador entre o material e o imaterial, o cultural e o natural.

Na Conferência Geral da United Nations Educational, Scientific and Cultural Organization (Unesco) de 1972, sediada em Paris, criaram-se as orientações para a implementação da Convenção do Patrimônio Mundial (Iphan, 2008). Foi a primeira vez que a terminologia patrimônio cultural foi citada oficialmente. Em 2008, em reunião do Comitê do Patrimônio Mundial para realização de novas orientações, realizaramse estudos e reflexões sobre as paisagens culturais e sua relação com a garantia da diversidade biológica e a melhoria dos valores naturais da paisagem (ARAÚJO, 2009).

A partir do princípio de que a paisagem é uma obra que conecta os patrimônios cultural e natural, surge o termo paisagem cultural. Afinal, a cultura é o agente propulsor dessa paisagem, que surge num sítio inato. A Unesco assim define paisagem cultural:

Paisagem Cultural: os bens culturais que representam obras conjuntas do ser humano e a natureza e ilustram a evolução da sociedade humana e seus assentamentos ao longo do tempo, condicionados pelas limitações e/ou pelas oportunidades físicas que apresenta seu entorno natural e pelas sucessivas forças sociais, econômicas e culturais, tanto externas como internas (Unesco, 2010, p. 3).

No Brasil, onde o tombamento de conjuntos arquitetônicos-paisagísticos prima pela conservação do sítio urbano por inteiro e preocupa-se com seu contexto e entorno, fica inerente à concepção de paisagem cultural. A preocupação não está na preservação de um bem isolado, mas na preservação da paisagem constituída como um todo: 
No tocante à própria conservação do sítio urbano, dever-se-á ter em vista manter tanto as peculiaridades de sua configuração geral, como os acidentes e outros elementos distintivos na paisagem natural existentes no terreno, quanto a disposição característica dos arruamentos, as modalidades arquitetônicas locais e a vegetação do domínio público e particular. [...] De outra parte, cumpre ter-se em mira proteger e beneficiar áreas circundantes, diligenciando-se para assegurar a ele a moldura panorâmica desejável, sem construções novas com destaque insólito, nem desaterros ou quaisquer empreendimentos contristadores (ANDRADE, 1987, p. 86).

O respeito à paisagem cultural não será alcançado se, para sua conservação e proteção, o desenvolvimento urbano tiver de ser podado. Então, não devem ser impostas à paisagem cultural apenas condicionantes do passado, mas a integração desse passado com as aspirações e necessidades da população atual. As cidades estão em contínua transformação, são dinâmicas e, segundo Castriota (2009), são bens tangíveis imóveis. Mas as modificações acontecem em camadas no decorrer da história e o tecido preexistente é recebido como herança e transformado por meio de intervenções representativas de cada época. As funções da cidade devem ser mantidas e diversificadas para sua sobrevivência:

Não se trata, portanto, de congelar a vida, ou de transformar as cidades em museus, mas em pensar na preservação e na melhoria de sua qualidade de vida, o que abrange tanto as áreas consideradas "históricas" quanto àquelas mais novas. [...] Pensar na cidade como um "patrimônio ambiental" é pensar, antes de mais nada, no sentido histórico e cultural que tem a paisagem urbana em seu conjunto, valorizando o processo vital que informa a cidade e não apenas monumentos "excepcionais" isolados (CASTRIOTA, 2009, p. 88).

O planejamento da paisagem, portanto, deve englobar políicas públicas urbanas que envolvam tantos os fatores naturais quanto os construídos, valorizando seu conjunto e sua história. No manual de orientações de implementação de ações em áreas urbanas centrais e cidades históricas (BRASIL, 2011) fica claro que a preservação do patrimônio cultural induz o desenvolvimento - necessário para superar cenários de degradação e subutilização e melhorar a qualidade urbana e social das cidades, que devem ser produtivas e resilientes.

\section{MUDANÇA CLIMÁTICA E TRANSTORNOS À PAISAGEM CULTURAL}

As alterações no clima são geradas por inúmeros fatores naturais, mas principalmente são respostas da intervenção humana. Desencadeiam a geração de eventos naturais diferentes em várias partes do mundo, como aumento ou diminuição da temperatura atmosférica, elevados índices pluviométricos, mudanças na temperatura dos oceanos e na umidade do ar, catástrofes como enchentes, tsunamis, ciclones. 
Em 1997 foi criado, no estado de Santa Catarina, o Centro de Informações de Recursos Ambientais e de Hidrometeorologia (Ciram), vinculado à Empresa de Pesquisa Agropecuária e Extensão Rural (Epagri), com a responsabilidade de levantar e monitorar os recursos naturais e o meio ambiente do estado. É responsável pelo monitoramento hidrometeorológico, pela gestão das mudanças climáticas e seus impactos na dinâmica das bacias hidrográficas e pelo monitoramento e análise de risco de eventos hidrológicos extremos.

Em 2015 muitas cidades do estado ficaram em alerta por conta das chuvas. Um estudo realizado por esses órgãos - em conjunto com o Instituto Nacional de Meteorologia (Inmet), o Instituto Nacional de Pesquisas Espaciais (INPE) e o apoio da Sociedade Brasileira de Meteorologia (Sbmet) - apontou o aumento da incidência de fenômenos de chuva intensa para Santa Catarina, conforme transcrito:

Avaliações do Quarto Relatório do IPCC (Intergovernamental Panelon Climate Change) e do Relatório de Clima do INPE têm mostrado que eventos extremos de precipitação podem tornar-se mais frequentes, podendo gerar enchentes e alagamentos mais severos e intensos [...]. Uma intensificação nos extremos de precipitação pode ser causada pelo aumento no conteúdo de umidade da atmosfera, o que pode aumentar sua disponibilidade para sistemas precipitantes associados a frentes, tempestades tropicais e extratropicais e complexos convectivos de mesoescala. As projeções de extremos de chuva até finais do século XXI, derivado dos modelos globais e regionais do IPCC e do INPE, para cenários de altas e baixas concentrações de gases de efeito estufa, mostram aumentos nas tendências de eventos extremos de chuva, especialmente no norte e litoral de Santa Catarina (Epagri, 2008, p. 57).

Alagamentos, inundações e enxurradas causam muitos transtornos aos patrimônios público e privado. Os prejuízos também alcançam a paisagem cultural, arrasando bens tombados, arrastando a pavimentação de vias de tráfego, poluindo os corpos hídricos. Herzog (2013) aponta que é preciso pensar de forma resiliente, ou seja, a cidade deve estar preparada para persistir e absorver essas mudanças, mantendo suas funções e propósitos.

Em 2010 a cidade paulista de São Luiz do Paraitinga sofreu com uma enchente oriunda de altos índices pluviométricos e um sistema de escoamento das águas precário. A integridade de seu patrimônio foi ameaçada: a cidade teve oito edifícios históricos, incluindo a Igreja Matriz - inaugurada no século XVII -, devastados (figuras 1 e 2).

Em 1985, Laguna, cidade do litoral catarinense, teve uma poligonal de tombamento delimitada para proteção do seu sítio inicial - rico em exemplares arquitetônicos do estilo luso-brasileiro, eclético e art déco -, um exemplo de patrimônio nacional que vem sofrendo com o aumento das chuvas. Sua área central fica em uma planície de aluvião entre a cadeia de morros e a lagoa Santo Antônio dos Anjos. A influência das mudanças climáticas, o processo de urbanização e o aumento da impermeabilidade do solo contribuíram para a ineficiência da drenagem urbana, provocando problemas na vazão e absorção das águas. A figura 3 representa a inundação da rua Tenente Bessa, 
ligação direta dos morros com a lagoa, em 2004. Os alagamentos são frequentes, tendo se intensificado a cada ano. As figuras 4 e 5 apresentam o mesmo trecho da cidade com inundações em 1974 e 2014.

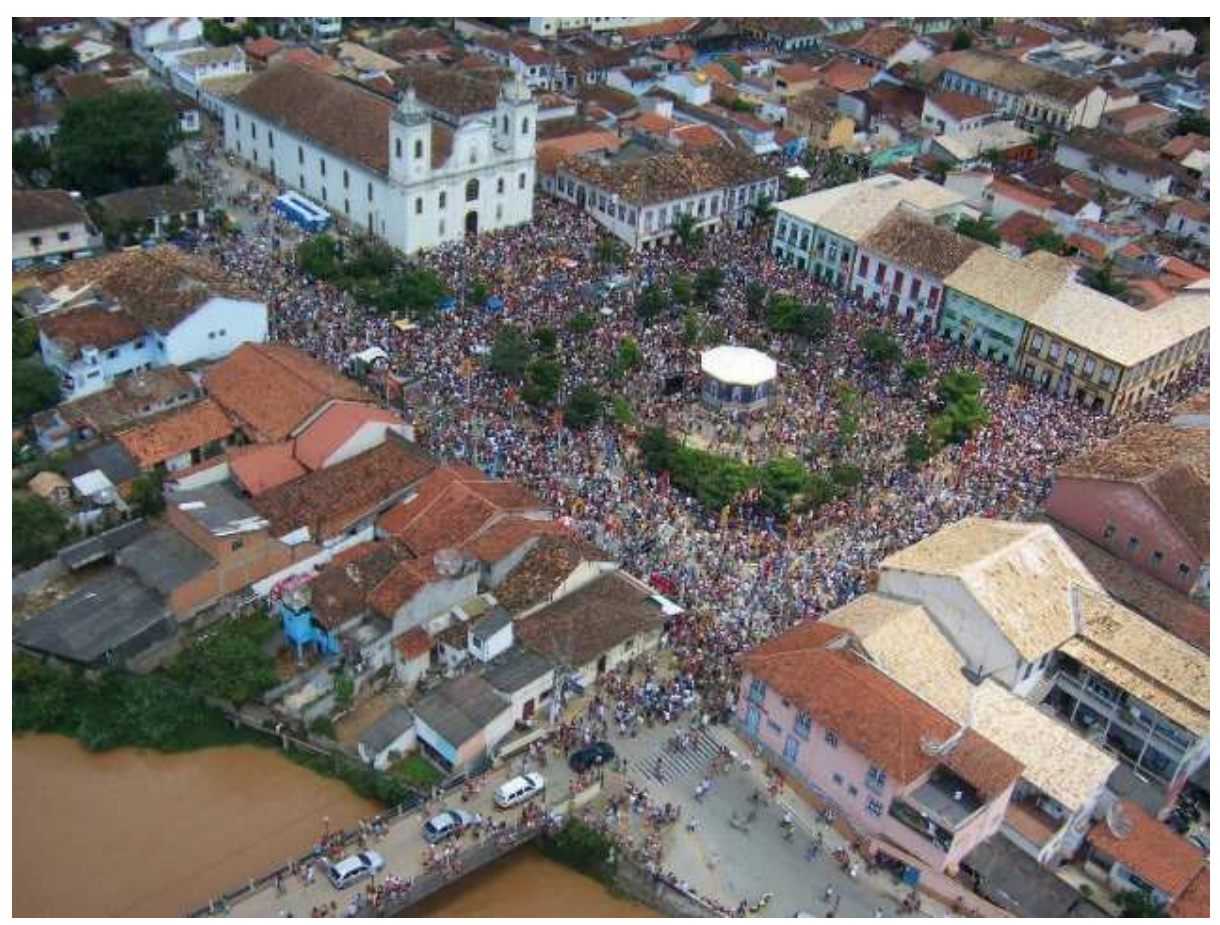

Figura 1 Igreja Matriz de São Luiz do Paraitinga (SP) e casario. Fonte: Prefeitura Municipal de São Luiz do Paraitinga, 2009.

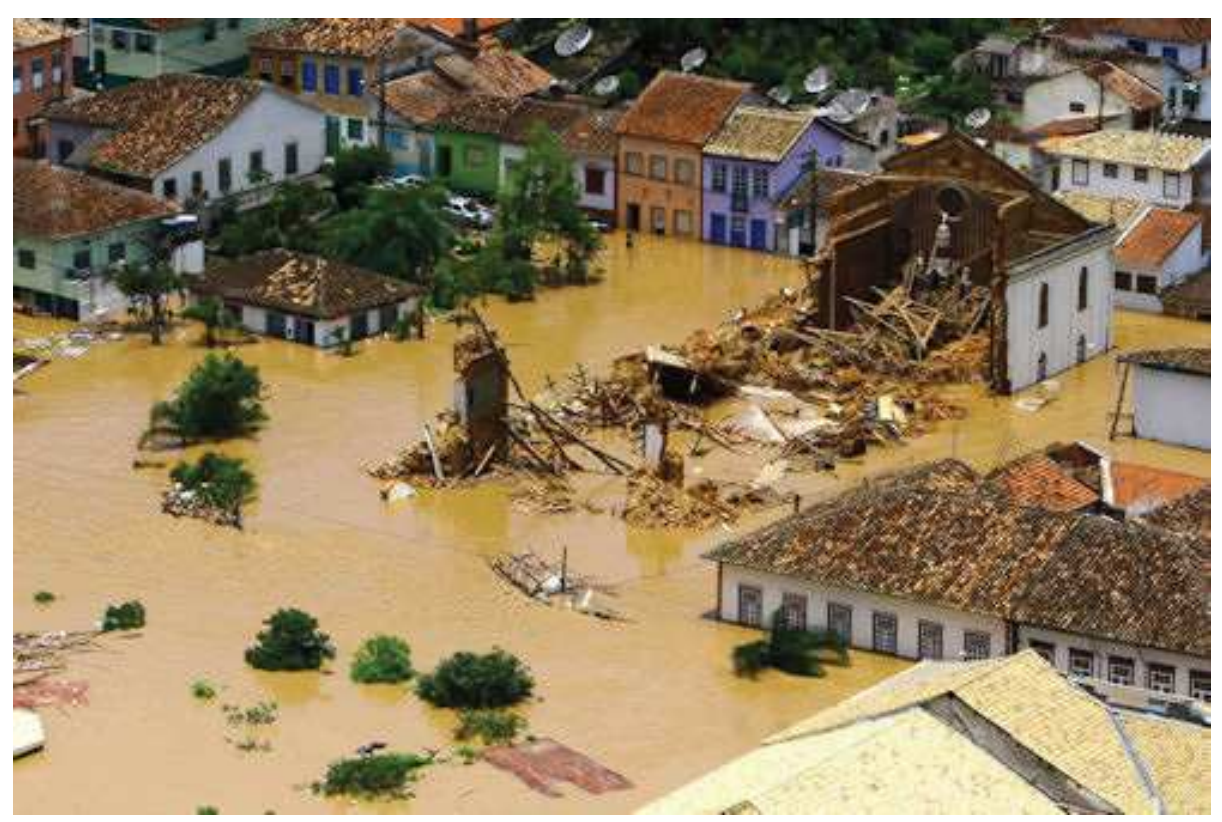

Figura 2 Escombro da Igreja Matriz de São Luiz do Paraitinga (SP) após a enchente de 2010. Fonte: Bocchini (2012). 
Espaços Livres Públicos: Utilização de Infraestrutura Verde para Otimizar a Drenagem Urbana nos Centros Históricos Tombados

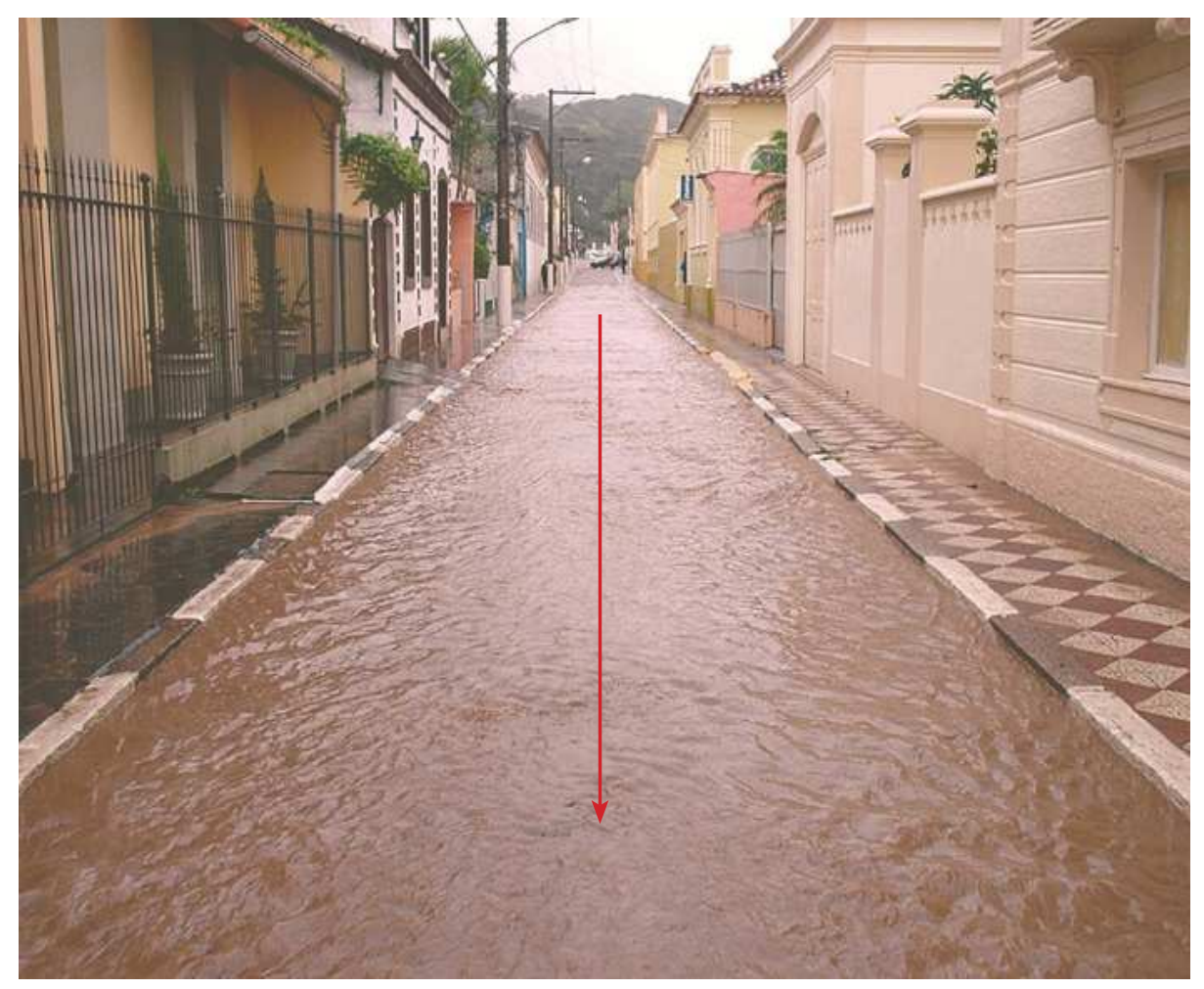

Figura 3 Inundação na rua Tenente Bessa, Laguna (SC), setembro de 2004. Fonte: Souza (2004, p. 3), adaptada por Claudione Medeiros, 2004.

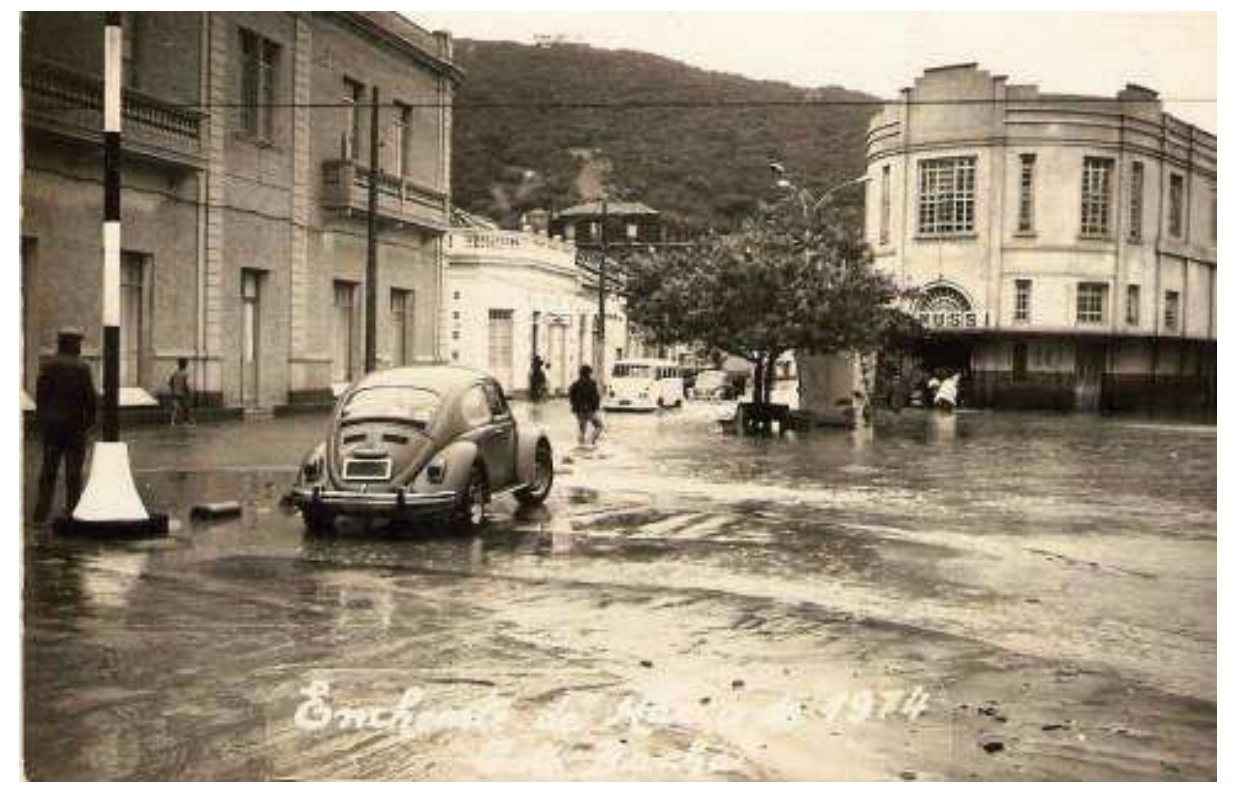

Figura 4 Inundação próximo ao cine teatro Mussi, Laguna (SC), março de 1974. Fonte: Foto Bacha, 2014. 


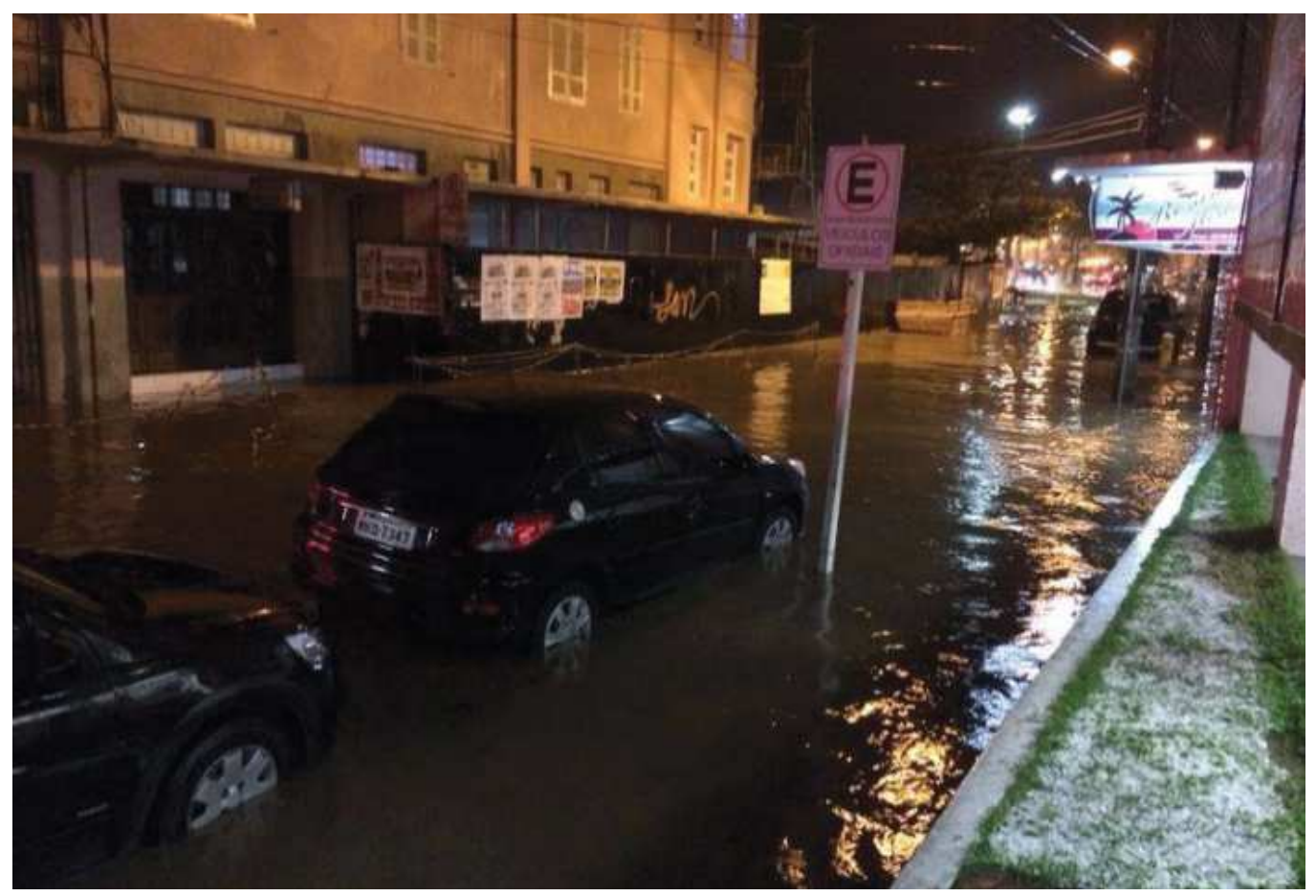

Figura 5 Inundação próximo ao cine teatro Mussi, Laguna (SC), agosto de 2014.

Foto: Graziele Sitônio, 2014.

Esses eventos naturais são cada vez mais frequentes e ameaçam principalmente as edificações. Podem ocasionar a perda total de patrimônios - como no caso de São Luiz do Paraitinga - ou morte lenta, com a intensificação da umidade ascendente no casario (figuras 6 a 10). As patologias geradas podem ser superficiais ou estruturais, como manchas e mofo nas paredes, pintura em processo de descascamento, desplacamento de reboco e emboço, fissuras, vegetação infestante na base do edifício - o que pode ser observado nos detalhes do embasamento dos edifícios pelo levantamento fotográfico registrado em julho de 2015, após fortes chuvas e alagamentos.

A utilização de infraestrutura verde, de acordo com Herzog (2010), pode otimizar as áreas permeáveis, promovendo o equilíbrio do ciclo hidrológico, aumentando a infiltração, a percolação e a evapotranspiração. Para Pellegrino (2014), além de melhorar a drenagem urbana e a qualidade das águas, esse tipo de infraestrutura contribui para a requalificação do paisagismo urbano, constituindo-se em novo movimento de criação de paisagens, que pode ser assim percebido:

[...] como parte de uma estratégia de implantação de espaços abertos urbanos, paisagisticamente tratados para serem muito mais que meras ações de embelezamento urbano, mas também para desempenharem funções infraestruturais relacionadas ao manejo das águas urbanas, conforto ambiental, biodiversidade, alternativas de circulação, acessibilidades e imagem local (CORMIER, PELLEGRINO, 2008, p. 127). 
Espaços Livres Públicos: Utilização de Infraestrutura Verde para Otimizar a Drenagem Urbana nos Centros Históricos Tombados

Assim, a forma urbana composta pelo conjunto de volumes construídos e pelos sistemas de espaços livres deixa de ser vista como um cenário para ser tratada como uma infraestrutura viva.

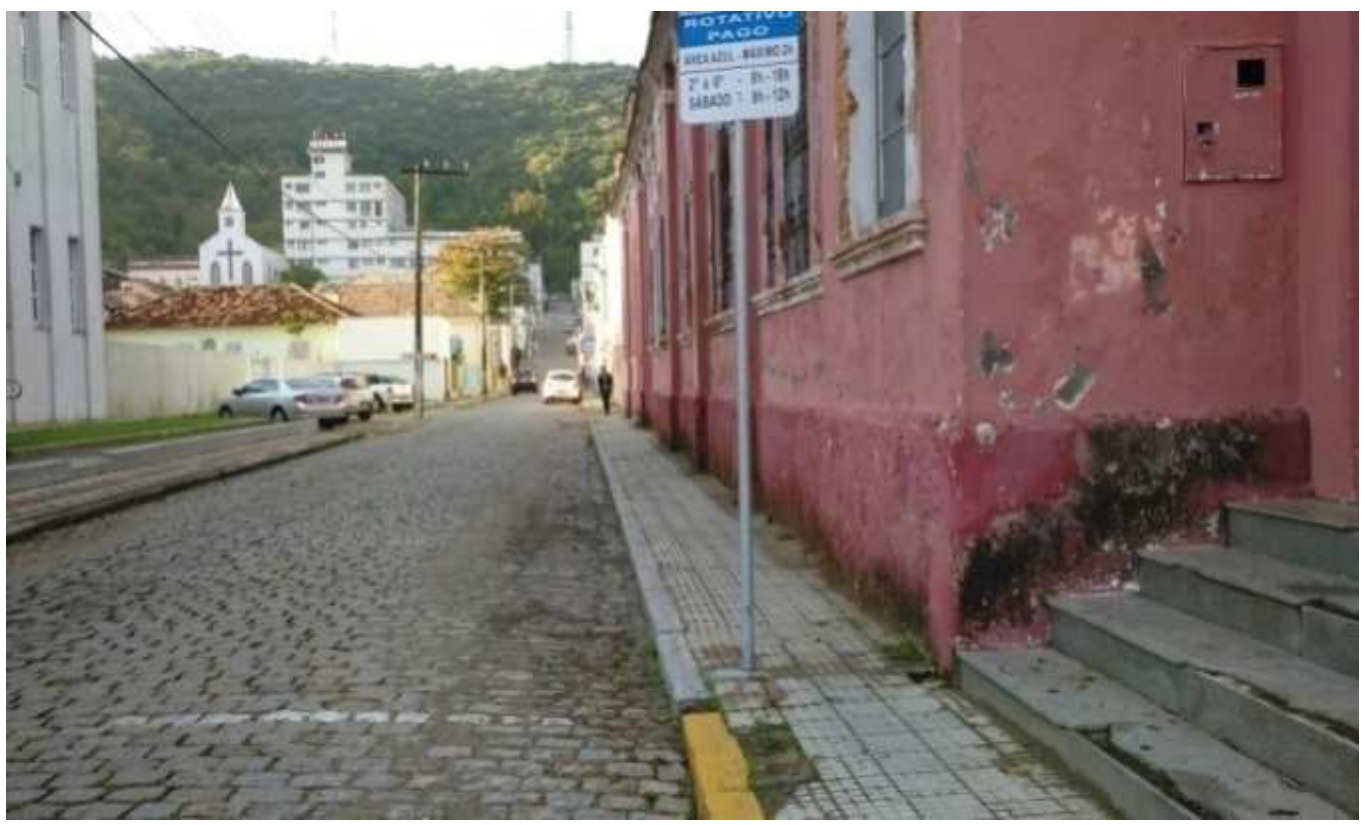

Figura 6 Rua Duque de Caxias, Clube Congresso Lagunense, exemplar eclético.

Foto: Claudione Medeiros, 2015.

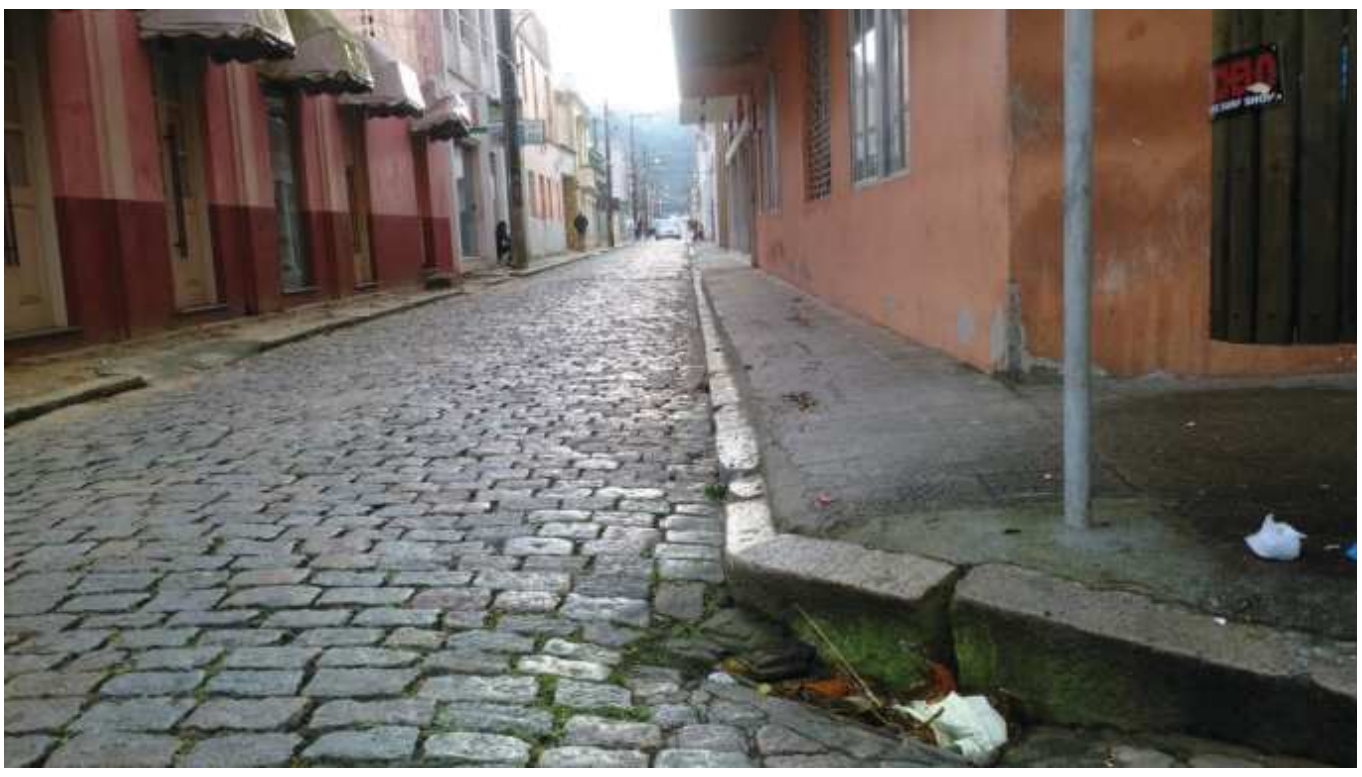

Figura 7 Rua Raulino Horn, Centrão Lanches, exemplar art déco. Foto: Claudione Medeiros, 2015. 


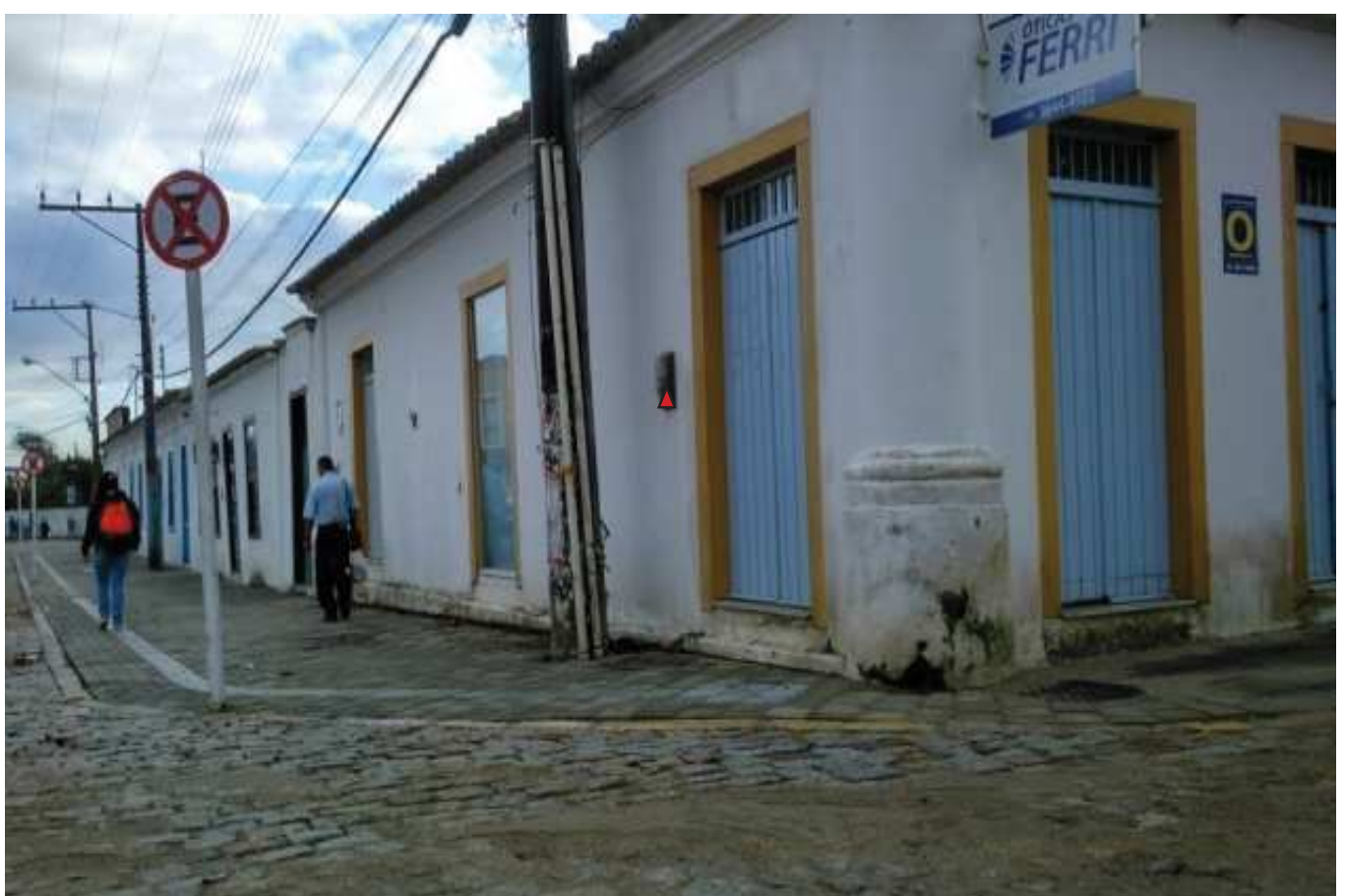

Figura 8 Casario na praça República Juliana, exemplar luso-brasileiro. Foto: Claudione Medeiros, 2015.

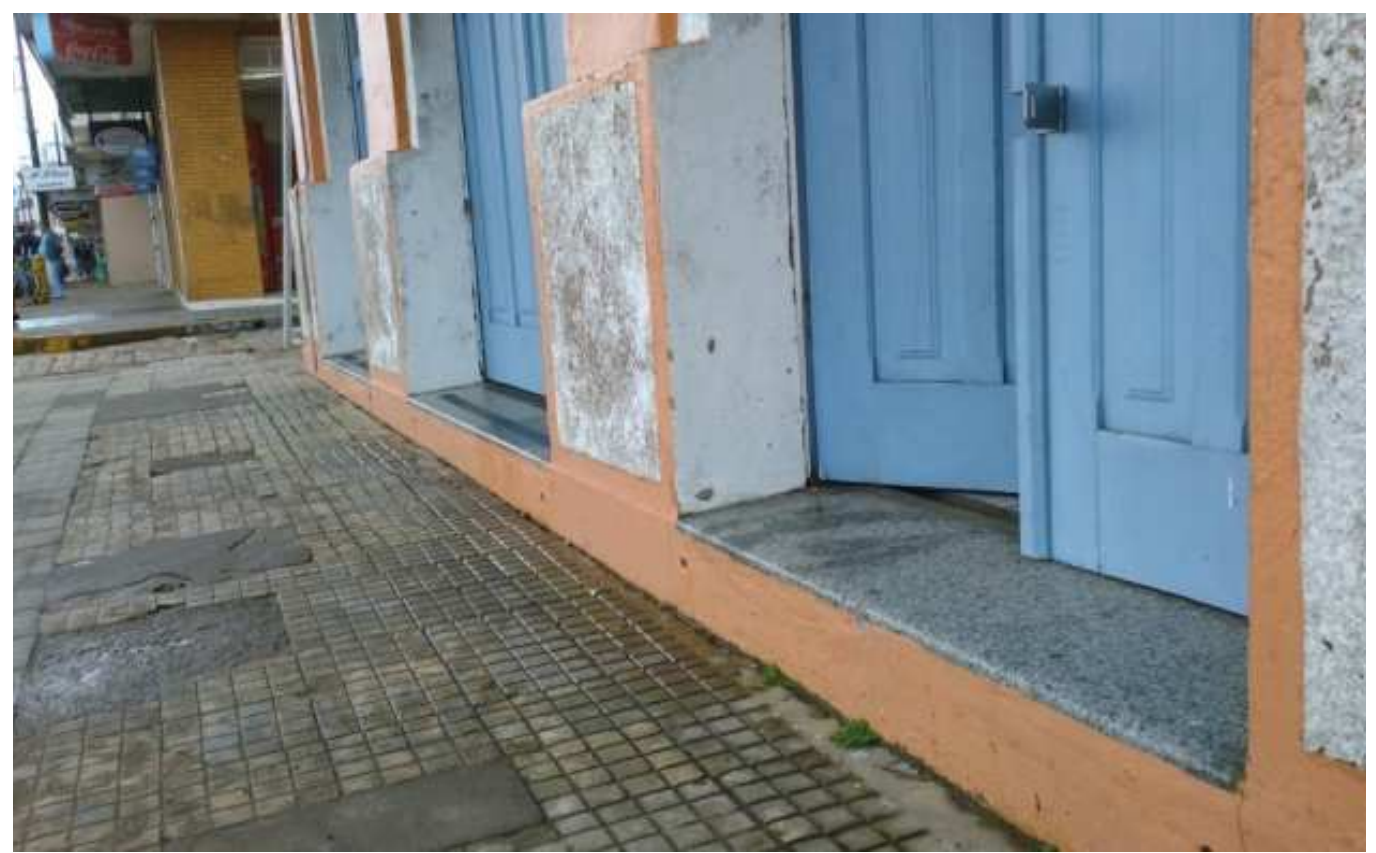

Figura 9 Casario no cruzamento da rua Gustavo Richard com o calçadão XV de Novembro, exemplar eclético. Foto: Claudione Medeiros, 2015. 


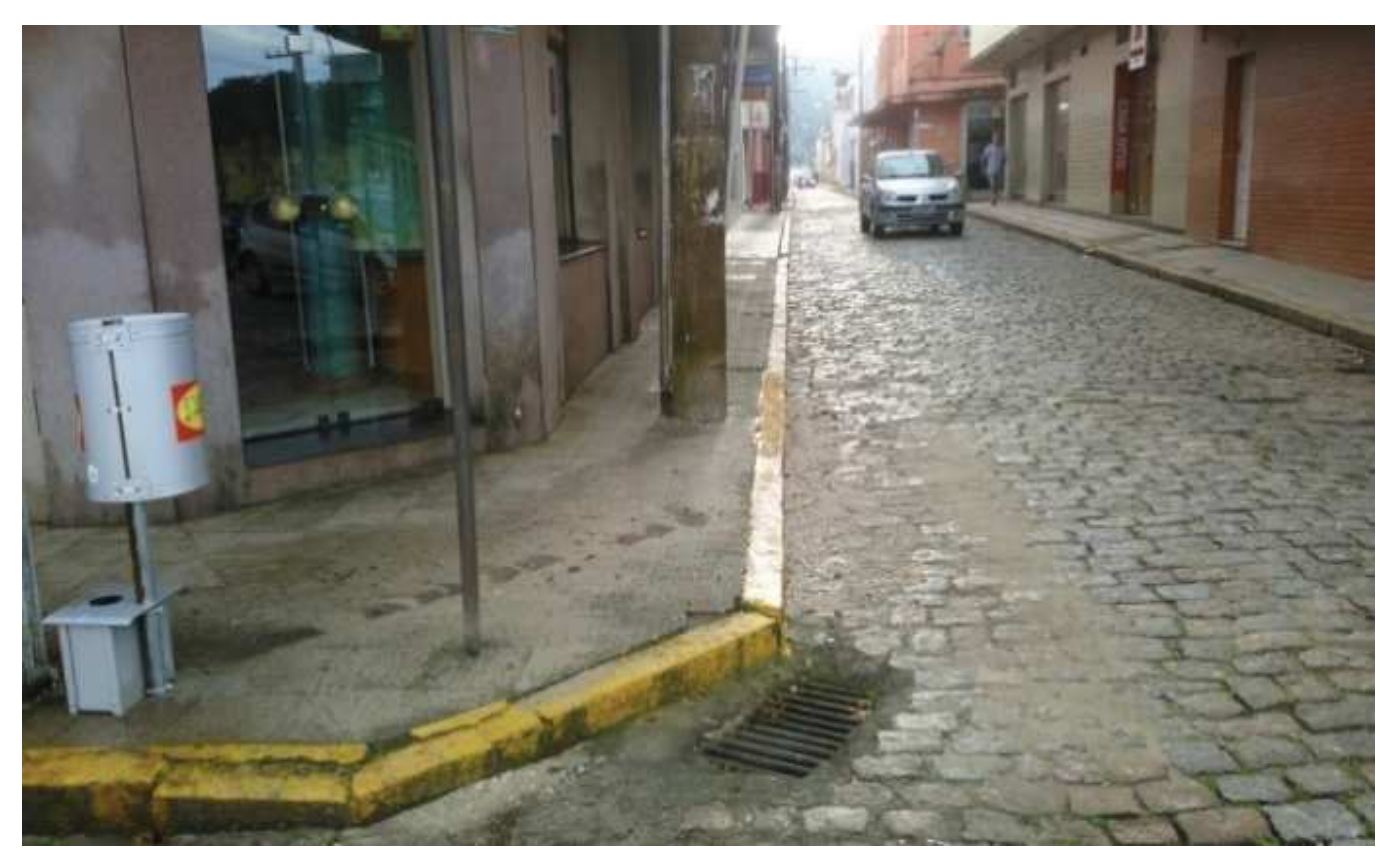

Figura 10 Casario no cruzamento da rua Gustavo Richard com a rua Tenente Bessa, exemplar art déco. Foto: Claudione Medeiros, 2015.

\section{INFRAESTRUTURA VERDE E RESILIÊNCIA URBANA}

'Resiliência' é um termo novo para os arquitetos e urbanistas. Foi usado em 2008, pelo designer e filósofo John Thackara, para transcrever muitos de seus pensamentos. Ele adota a definição de resiliência como "[...] a capacidade de um sistema absorver perturbações e se reorganizar, enquanto submetido à mudança" (BALTAZAR, 2010). A resiliência de uma cidade, então, é a sua capacidade de manter-se viva mesmo exposta a mudanças climáticas, econômicas ou sociais.

Pellegrino (2014) defende que as alterações climáticas, somadas à evolução urbana e ao aumento de áreas impermeabilizadas, contribuem para a aceleração de conturbações e tornam as cidades mais vulneráveis. $\bigcirc$ projeto paisagístico e os sistemas de espaços livres devem contribuir para aumentar a capacidade de superação, reorganização e recuperação das áreas consolidadas:

As cidades precisam se adaptar às mudanças climáticas para se tornarem resilientes aos impactos ambientais. As questões ambientais, como a conservação das áreas verdes, o uso adequado do solo e da água e melhores condições do ar, levando em consideração o transporte limpo, são pontos primordiais para o planejamento urbano sustentável. Todos devem ser reunidos em um plano integrado de infraestrutura verde - um meio de recuperar o ambiente urbano e melhorar a qualidade de vida da população atual, assim como das gerações futuras sem agredir o ambiente natural (BUENO; XIMENES, 2011, p. 6). 
Deve-se primar por intervenções que aumentem a capacidade de resposta das cidades em face dos eventos climáticos, promovendo-se o aumento do seu grau de resiliência. A infraestrutura verde se insere nesse contexto como instrumento de drenagem urbana e planejamento urbano sustentável, em que vários aspectos e questões são revistos em busca de sistemas de infraestrutura flexíveis e adaptáveis. As cidades do século XXI buscam uma expressão qualitativa do lugar, com a premissa de melhorar a qualidade de vida de seus habitantes. $\bigcirc$ equilíbrio entre sociedade e ambiente influi na produção dessa paisagem e na proposição de novas intervenções que conectam as composições ambientais, sociais, econômicas e culturais.

Para auxiliar os sistemas de águas urbanas de forma sustentável, surge a infraestrutura verde. Ela tem o papel de conectora dos ecossistemas do meio urbano, sem desprezar as condicionantes de mobilidade e acessibilidade e as características histórico-culturais do lugar. Herzog reforça essa relevância:

A infraestrutura verde visa mitigar os efeitos da urbanização em diversas escalas e com equipes multidisciplinares, para que os aspectos abióticos, bióticos e socioculturais sejam balizadores de planejamentos e projetos integrados de médio e longo prazo. É bom ressaltar que as mudanças climáticas, que já estão ocorrendo devem ser consideradas de modo a adaptar as cidades para que seus efeitos sejam minorados ou mesmo evitados. A infraestrutura verde pode contribuir significativamente nessa adaptação, pois restabelece os serviços ecológicos eliminados durante a urbanização tradicional (HERZOG, 2010, p. 3).

A infraestrutura verde vem sendo aplicada em muitos projetos internacionais. Exemplos significativos dessa nova maneira de gerenciar as águas das chuvas são os aplicados nos estados americanos de Oregon e Washington e na província da Colúmbia Britânica, citados por Cormier e Pellegrino (2008), que reiteram a importância da criação dessas paisagens urbanas buscando reatar as funções naturais dos ecossistemas. Esse novo movimento de criação de paisagens urbanas pode ser percebido:

[...] como parte de uma estratégia de implantação de espaços abertos urbanos, paisagisticamente tratados para serem muito mais que meras ações de embelezamento urbano, mas também para desempenharem funções infraestruturais relacionadas ao manejo das águas urbanas, conforto ambiental, biodiversidade, alternativas de circulação, acessibilidades e imagem local (CORMIER, PELLEGRINO, 2008, p. 127).

Segundo Pellegrino (2014), essa infraestrutura pode ser dividida em dois grupos: o primeiro com a adoção de sistemas vivos, tendo como matéria-prima a vegetação; o segundo depende de processos físicos, e, embora também receba o nome de infraestrutura verde, não necessariamente precisa se constituir de elementos vivos. $\bigcirc$ conceito está baseado na coleta e retenção das águas das chuvas e no acréscimo de área vegetada, diminuindo o escoamento superficial, a erosão e a quantidade de polvição difusa transportada pelas primeiras chuvas aos corpos hídricos. 
São consideradas infraestruturas verdes várias tipologias, como parques lineares, lagoas pluviais, biovaletas, jardins de chuva, canteiros pluviais, tetos e paredes, bacias de detenção, poços secos, filtros de areia, trincheiras ou valetas de infiltração, pavimentos porosos e cisternas para a coleta e reaproveitamento das águas de chuva. $\bigcirc$ agrupamento de algumas tipologias forma uma grade, ou rede verde, que deve ser estabelecida a partir de estudos da bacia de contribuição.

\section{APLICAÇÃO DA INFRAESTRUTURA VERDE \\ NOS SISTEMAS DE ESPAÇOS LIVRES PÚBLICOS: ESTUDO DE CASO DA CIDADE DE LAGUNA (SC)}

Para exemplificar a possibilidade de aplicação de infraestrutura verde nos sistemas de espaços livres públicos em centros históricos tombados, escolhemos a cidade de Laguna (SC) como estudo de caso (figura 11). O seu centro urbano foi tombado em 1985, quando foi delimitada uma poligonal de tombamento com inscrição no Livro do Tombo Arqueológico, Etnográfico e Paisagístico da Subsecretaria do Patrimônio Histórico e Artístico Nacional. Essa poligonal é constituída por uma linha imaginária que coincide com a formação de uma bacia de contribuição, passando pelos cumes dos morros e adentrando 200 metros para a Lagoa (figura 12). A área delimitada apresenta grande acervo arquitetônico e paisagístico, configurando-se um grande museu a céu aberto.

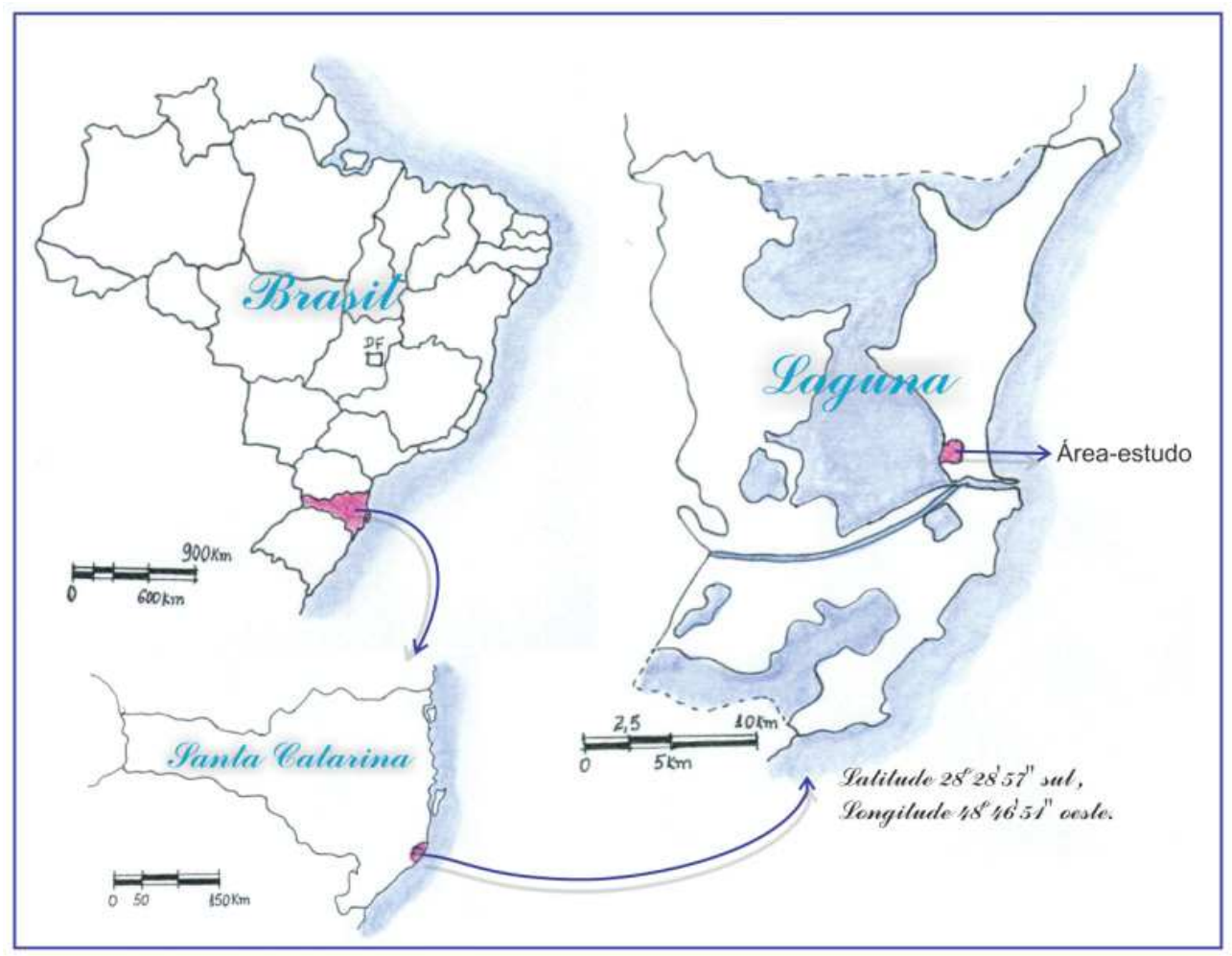

Figura 11 Localização de Laguna (SC).

Fonte: Medeiros (2015, p. 87). 


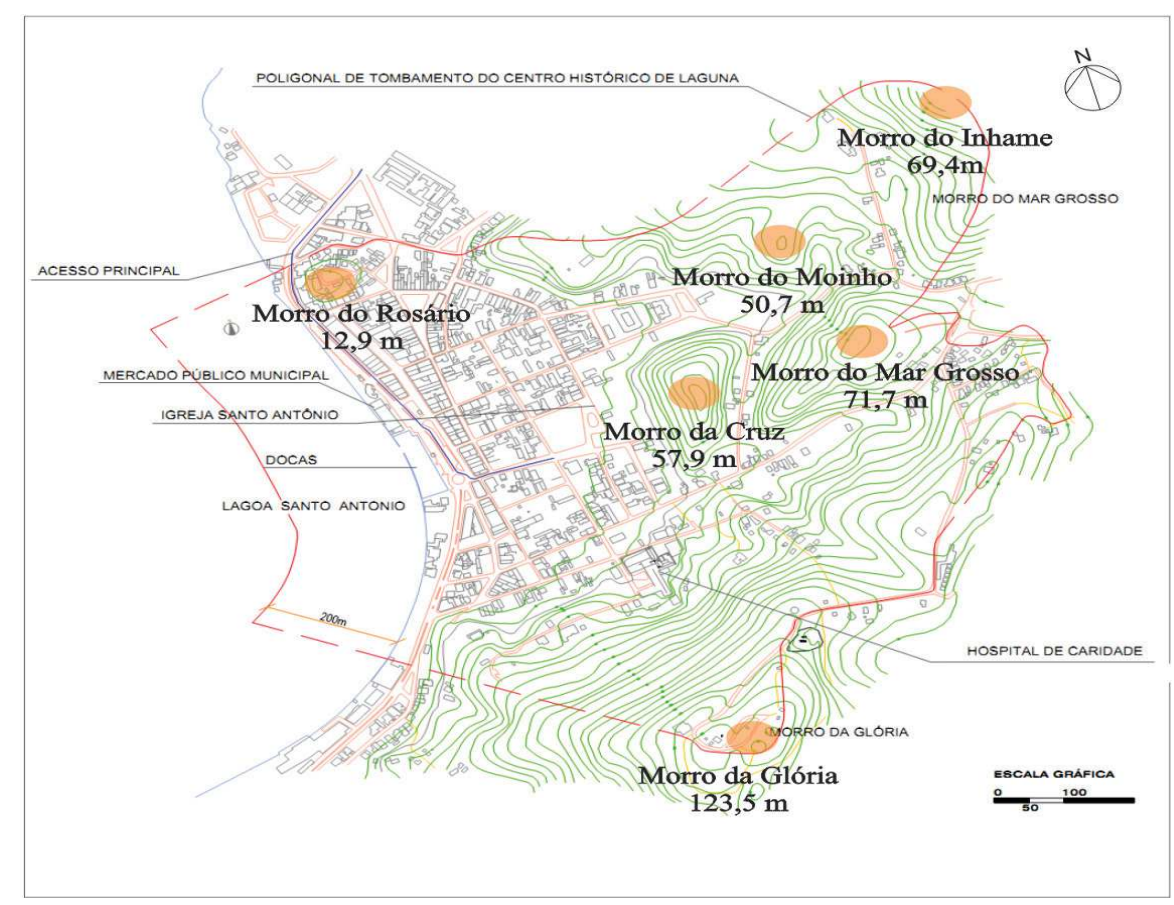

Figura 12 Mapa planialtimétrico indicando a linha imaginária da Poligonal de Tombamento do Centro de Laguna. Fonte: Base cartográfica do Iphan, elaborado por Claudione Medeiros, 2014.

A área do estudo encontra-se consolidada (figura 13), portanto não cabe aqui a criação de novas áreas livres que venham a descaracterizar o patrimônio nacional. No entanto, ao reabilitar as áreas existentes, foram criados novos espaços livres públicos. Nesse caso é preciso identificar os espaços como adaptáveis à infraestrutura verde ou não, além de seguir as determinações do Iphan quanto à identificação de jardins históricos.

Para esse processo sistemático da pesquisa foram utilizadas visitas exploratórias com observação e levantamento fotográfico; foi desenvolvido um zoneamento dos espaços livres públicos nos mapas fornecidos pelo escritório técnico do Iphan e gerados mapas utilizando o programa de processamento geoespacial ArcGIS - por meio de dados fornecidos pela Secretaria do Estado de Santa Catarina -, utilizando o Sistema de Informações Geográficas (SIG) como ferramenta para a identificação dos talvegues e a determinação das melhores áreas para a instalação das infraestruturas verdes.

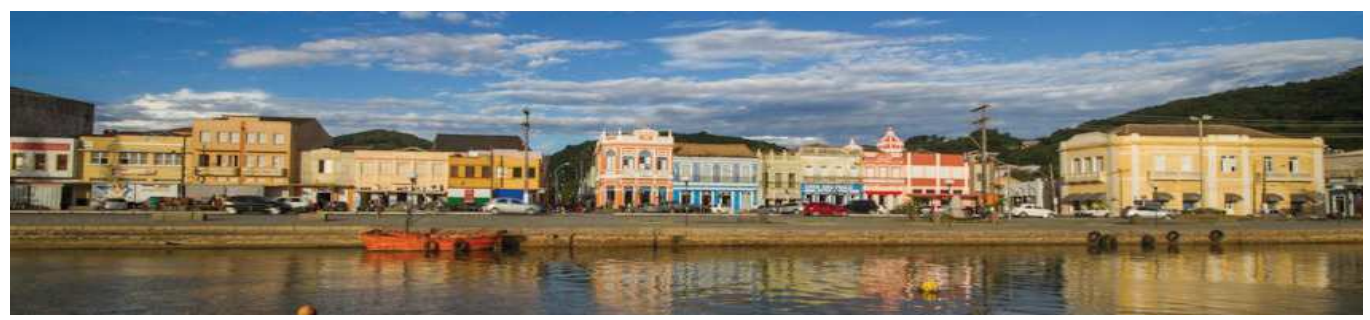

Figura 13 Vista do Centro Histórico Tombado de Laguna a partir da lagoa Santo Antônio. Foto: Ronaldo Amboni, 2015. 
Partiu-se da localização dos espaços livres já inseridos no contexto da cidade, descartando as áreas dos morros com remanescentes de mata atlântica, que devem permanecer inalteradas tanto por força de lei quanto pelo entendimento da equipe (figura 14). A configuração da bacia de contribuição é a ligação principal entre uma cadeia de morros e a lagoa Santo Antônio dos Anjos da Laguna, que pode ser observada através do mapa hipsométrico gerado (figura 15). Esses espaços recriados servirão de trampolins ecológicos, que, conectados, contribuirão para a restituição do ciclo hidrológico na cidade e a qualificação da paisagem:

Em uma cidade seria uma grande limitação depender apenas de áreas de preservação permanente para a conservação da biodiversidade, destacando-se então a importância dos projetos de espaços abertos públicos e privados que apresentem uma variedade de situações, permitindo, de algum modo, o seu desempenho como trampolins ecológicos, nas áreas ocupadas por habitações e outros usos urbanos. Sem enfrentar essa necessidade por tais conexões, se torna cada vez mais difícil a manutenção de espécies nativas significativas em paisagens cada vez mais transformadas (PELLEGRINO, 2014, p. 18).

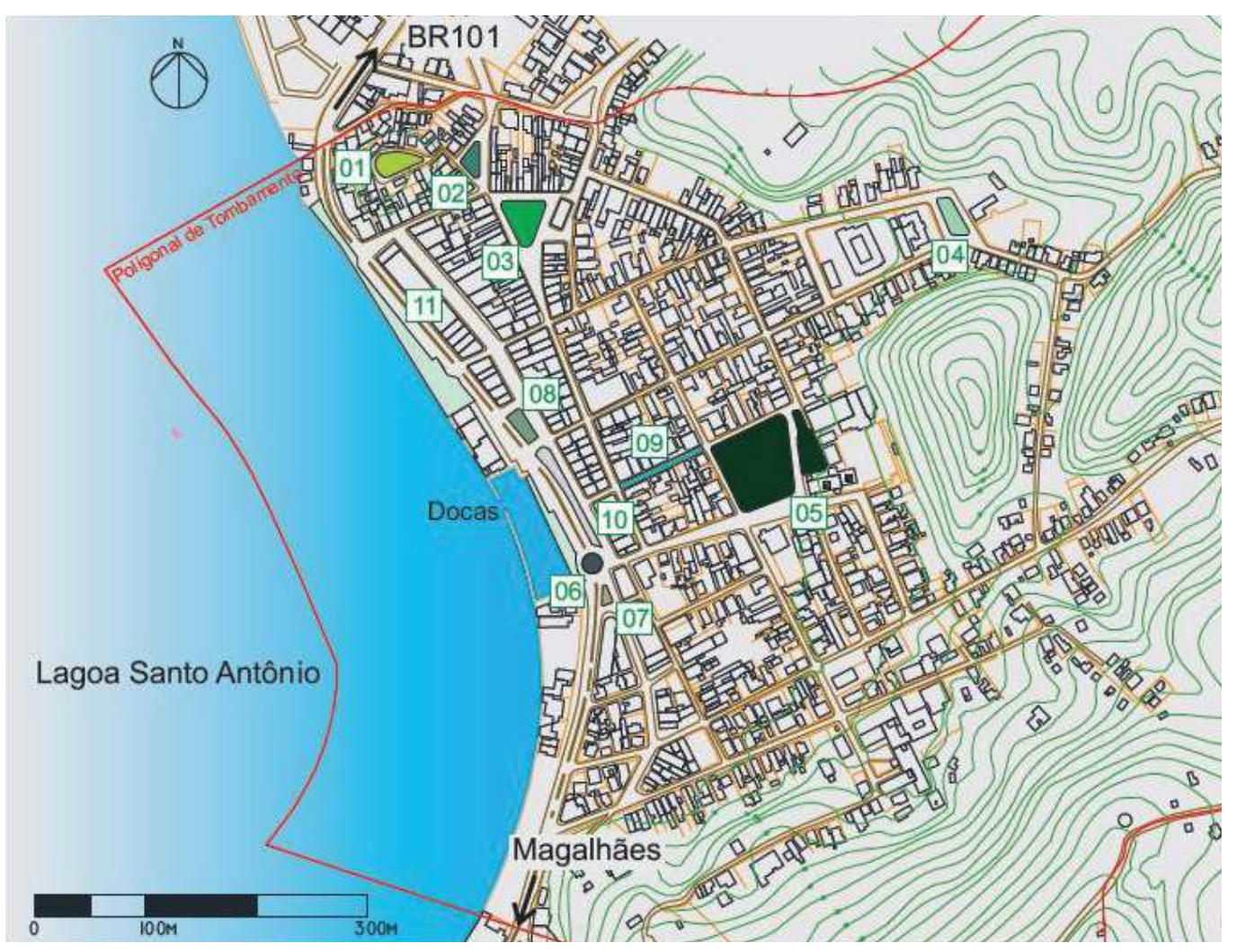

Figura 14 Mapa índice do quadro.

Fonte: Mapa produzido em 2015 por Claudione Medeiros sobre base cartográfica do Iphan. 

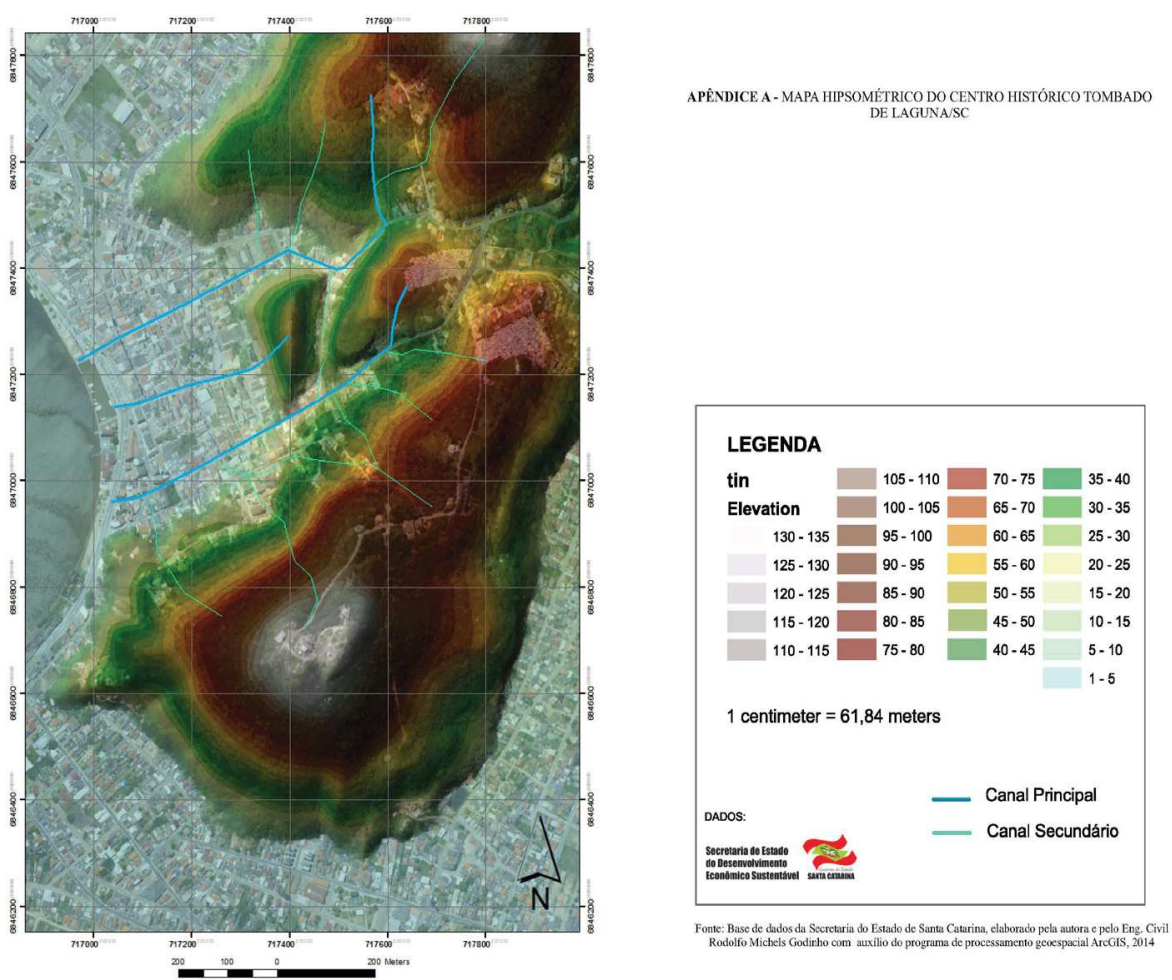

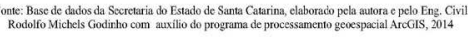

Figura 15 Mapa hipsométrico gerado com sobreposição de imagens da foto aérea com a topografia local. Fonte: Mapa produzido em 2014 por Claudione Medeiros e Rodolfo Godinho com auxílio do programa de processamento geoespacial ArcGIS, utilizando a base de dados da Secretaria Regional do Estado de Santa Catarina.

O quadro a seguir apresenta a análise dos espaços livres identificados de acordo com o tipo de qualidade descrito por Macedo (1993): ambiental, funcional e estética. A concepção ambiental deve abranger o conforto e a sustentabilidade baseada na tríade: ambiente, social e econômico. Na concepção funcional observam-se as demandas, o programa existente, a acessibilidade, a infraestrutura e os mobiliários e equipamentos, estados de conservação e ergonomia. Na concepção estética, talvez a mais intáctil de todas, por submeter-se a valores que, mutáveis dependendo do tempo, do espaço e da sociedade, foram analisados a forma e as composições. Incluímos a concepção cultural/histórica para determinar quais desses espaços devem ser considerados jardins históricos - e ter tipologias arquitetônicas preservadas de acordo com as noções de patrimônio - e seguir o Manual de Intervenções em Jardins Históricos (Iphan, 2005), que descreve os conceitos básicos de preservação, incluindo valores, integridade, autenticidade e entorno do jardim. A Carta de Florença descreve como deve ser feita tal intervenção:

Art. 1. Um jardim histórico é uma composição arquitetônica e vegetal que, do ponto de vista da história e da arte, apresenta um interesse público. Como tal é considerado monumento.

Art. 9. A proteção dos jardins históricos exige que eles sejam identificados e inven- 
tariados. Impõe intervenções diferenciadas que são: a manutenção, a conservação, a restauração. Pode-se eventualmente recomendar a restituição. A autenticidade diz respeito tanto no desenho e ao volume de partes quanto ao seu cenário ou à escolha de vegetais ou de minerais que os constituem.

Art. 10. Qualquer operação de manutenção, de conservação, restauração ou restituição de um jardim histórico ou de uma de suas partes deve considerar simultaneamente todos os seus elementos. Separar-lhes os tratamentos alteraria os laços que os unem. Art. 15. Qualquer restauração e, com mais forte razão, qualquer restituição de um jardim histórico só serão empreendidas após um dos documentos referentes ao respectivo jardim e aos jardins análogos, suscetível de assegurar o caráter científico da intervenção. Antes de qualquer execução, esse estudo deverá resultar em um projeto que será submetido a um exame e a uma aprovação colegiados.

Art. 16. A intervenção de restauração deve respeitar a evolução do respectivo jardim. Em princípio, ela não deveria privilegiar uma época à custa de outra, salvo se a degradação ou o definhamento de certas partes puderem, excepcionalmente, dar ensejo a uma reconstituição fundada sobre vestígios ou sobre uma documentação irrecusável. Poderão ser, mais particularmente, objeto de uma restituição eventual as partes de um jardim mais próximas do edifício a fim de fazer ressaltar sua coerência. Art. 17. Quando um jardim houver desaparecido totalmente ou quando só possuírem elementos conjecturais de seus estados sucessivos, não poderá empreender uma restituição relevante da noção de jardim histórico.

Os trabalhos que, neste caso, se inspiram em formas tradicionais sobre o terreno de um jardim antigo, ou em lugar onde nenhum jardim tenha previamente existido, constituiriam, então, noções de evocação ou de criação, excluída qualquer qualificação de jardim histórico. Carta de Florença, 1981 (CURY, 2004).

As modificações que devem ser evitadas são as que possam deteriorar a qualidade do jardim e seu entorno. O Iphan apoia sempre as intervenções que contribuem para a integridade e preservação, respeitando a estética da paisagem e a funcionalidade do espaço.

Quadro síntese da análise dos espaços livres públicos de Laguna (SC)

\begin{tabular}{|c|c|c|c|c|}
\hline $\begin{array}{c}\text { ESPAÇOS } \\
\text { LIVRES } \\
\text { PÚBLICOS }\end{array}$ & $\begin{array}{l}\text { CONCEPÇÃO } \\
\text { AMBIENTAL }\end{array}$ & $\begin{array}{l}\text { CONCEPÇÃO } \\
\text { FUNCIONAL }\end{array}$ & $\begin{array}{l}\text { CONCEPÇÃO } \\
\text { ESTÉTICA }\end{array}$ & $\begin{array}{c}\text { CONCEPÇÃO } \\
\text { CULTURAL/HISTÓRICA }\end{array}$ \\
\hline $\begin{array}{l}\text { De acordo } \\
\text { com as visitas } \\
\text { exploratórias, } \\
\text { levantamento } \\
\text { fotográfico } \\
\text { e análise do } \\
\text { SIG. }\end{array}$ & $\begin{array}{l}\text { Critérios de } \\
\text { conforto e } \\
\text { sustentabi- } \\
\text { lidade. Per- } \\
\text { meabilidade } \\
\text { do solo e } \\
\text { vegetação } \\
\text { nativa ou } \\
\text { relevante. }\end{array}$ & $\begin{array}{l}\text { Critérios de } \\
\text { acessibilidade, } \\
\text { infraestrutura, } \\
\text { mobiliários e } \\
\text { equipamentos } \\
\text { existentes, estado } \\
\text { de conservação e } \\
\text { ergonomia. }\end{array}$ & $\begin{array}{l}\text { Critérios quanto } \\
\text { à forma e com- } \\
\text { posição. Foram } \\
\text { arguidos técnicos } \\
\text { do Iphan quanto } \\
\text { aos elementos } \\
\text { considerados } \\
\text { marcantes pelo } \\
\text { Instituto. }\end{array}$ & $\begin{array}{l}\text { Foram analisados: história } \\
\text { do local, valores, integridade, } \\
\text { autenticidade e entorno. A } \\
\text { integridade dos espaços e a } \\
\text { representatividade de sua épo- } \\
\text { ca foram determinantes para a } \\
\text { análise e a posição deste como } \\
\text { jardim histórico ou não. Foram } \\
\text { realizadas reuniões no escritório } \\
\text { técnico do Iphan para essas } \\
\text { análises. }\end{array}$ \\
\hline
\end{tabular}




\begin{tabular}{|c|c|c|c|c|}
\hline $\begin{array}{l}\text { ESPAÇOS LIVRES } \\
\text { PÚBLICOS }\end{array}$ & $\begin{array}{l}\text { CONCEPÇÃO } \\
\text { AMBIENTAL }\end{array}$ & $\begin{array}{l}\text { CONCEPÇÃO } \\
\text { FUNCIONAL }\end{array}$ & $\begin{array}{l}\text { CONCEPÇ̃̃o } \\
\text { ESTÉTICA }\end{array}$ & $\begin{array}{l}\text { CONCEPÇÃO } \\
\text { CULTURAL/ } \\
\text { HISTÓRICA }\end{array}$ \\
\hline Morro do Rosár & $\begin{array}{l}\text { Não possui } \\
\text { vegetação de } \\
\text { destaque, po- } \\
\text { rém sua per- } \\
\text { meabilidade é } \\
\text { garantida pela } \\
\text { área pública, } \\
\text { um terreno } \\
\text { baldio central } \\
\text { e inclinado. }\end{array}$ & $\begin{array}{l}\text { Não possui } \\
\text { mobiliário ou } \\
\text { equipamento; } \\
\text { não tem acessibi- } \\
\text { lidade e traçado } \\
\text { a ser preservado. } \\
\text { Lugar não apro- } \\
\text { veitado, inserido } \\
\text { na centralidade. }\end{array}$ & $\begin{array}{l}\text { Inexistência } \\
\text { de elementos } \\
\text { para avaliação } \\
\text { de qualidade } \\
\text { estética. }\end{array}$ & $\begin{array}{l}\text { Em } 1845 \text { tinha } \\
\text { em seu cume a } \\
\text { capela Nossa } \\
\text { Senhora do Rosá- } \\
\text { rio dos Homens } \\
\text { Pretos, construída } \\
\text { por escravos. Até } \\
1996 \text { existiam } \\
\text { suas ruínas; } \\
\text { hoje há apenas } \\
\text { vestígios. } \\
\text { Não representa } \\
\text { um jardim histó- } \\
\text { rico. }\end{array}$ \\
\hline 02 & $\begin{array}{l}\text { Possui uma } \\
\text { figueira e } \\
\text { canteiros com } \\
\text { grama. Próxi- } \\
\text { mo ao morro } \\
\text { do Rosário. }\end{array}$ & $\begin{array}{l}\text { Possui mobiliário } \\
\text { urbano: dois } \\
\text { bancos e uma } \\
\text { mesa, porém } \\
\text { muito danifica- } \\
\text { dos. Não possui } \\
\text { lixeiras. Seu } \\
\text { entorno é ocupa- } \\
\text { do por casas, a } \\
\text { maioria com uso } \\
\text { comercial. }\end{array}$ & $\begin{array}{l}\text { Possui traçado } \\
\text { triangular e } \\
\text { monumento em } \\
\text { homenagem } \\
\text { a Jerônimo } \\
\text { Coelho. }\end{array}$ & $\begin{array}{l}\text { Formou-se a par- } \\
\text { tir da demolição } \\
\text { de casas. Não } \\
\text { representa um } \\
\text { jardim histórico. }\end{array}$ \\
\hline Praça & $\begin{array}{l}\text { Sua vegetação } \\
\text { original foi } \\
\text { subtraída em } \\
\text { intervenções } \\
\text { para trans- } \\
\text { formá-la em } \\
\text { praça para } \\
\text { eventos. Possui } \\
\text { amendoeiras } \\
\text { que pro- } \\
\text { porcionam } \\
\text { sombra. }\end{array}$ & $\begin{array}{l}\text { Possui desenho } \\
\text { triangular, rede } \\
\text { de distribuição } \\
\text { subterrânea e } \\
\text { bancos em bom } \\
\text { estado. }\end{array}$ & $\begin{array}{l}\text { Possui mo- } \\
\text { numento em } \\
\text { homenagem } \\
\text { à Anita Gari- } \\
\text { baldi e, no seu } \\
\text { entorno, prédios } \\
\text { da Câmara e } \\
\text { cadeia, sobrados } \\
\text { luso-brasileiros e } \\
\text { ecléticos. }\end{array}$ & $\begin{array}{l}\text { Já foi praça da } \\
\text { Cadeia, Conde } \\
\text { D'Eu, Conse- } \\
\text { Iheiro Mafra e } \\
\text { praça da Ban- } \\
\text { deira. Palco de } \\
\text { acontecimentos } \\
\text { históricos, como } \\
\text { a Proclamação } \\
\text { da República em } \\
1839 \text {. } \\
\text { Não representa } \\
\text { um jardim histó- } \\
\text { rico. }\end{array}$ \\
\hline 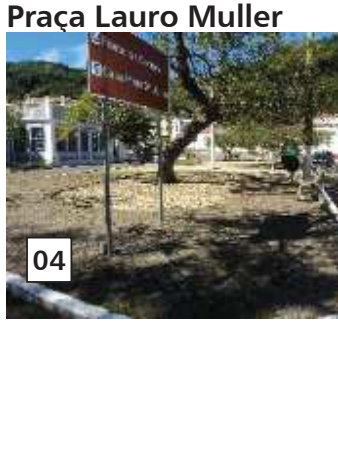 & $\begin{array}{l}\text { Não possui } \\
\text { elementos } \\
\text { significativos } \\
\text { de vegeta- } \\
\text { ção, além de } \\
\text { uma aroeira } \\
\text { ao centro. } \\
\text { Próximo ao } \\
\text { sopé do morro } \\
\text { do Moinho e } \\
\text { da fonte da } \\
\text { Carioca. }\end{array}$ & $\begin{array}{l}\text { Possui formato } \\
\text { triangular, dois } \\
\text { bancos e um } \\
\text { conjunto de } \\
\text { lixeiras. }\end{array}$ & $\begin{array}{l}\text { Da praça, visua- } \\
\text { liza-se a fonte da } \\
\text { Carioca e a casa } \\
\text { Pinto D'Ullysséa. }\end{array}$ & $\begin{array}{l}\text { Surgiu junto com } \\
\text { a construção do } \\
\text { colégio Jerônimo } \\
\text { Coelho e do } \\
\text { posto de saúde } \\
\text { em 1911. Antes o } \\
\text { local se configu- } \\
\text { rava como um } \\
\text { alagado para as } \\
\text { lavadeiras. Não } \\
\text { representa um } \\
\text { jardim histórico. }\end{array}$ \\
\hline
\end{tabular}


Espaços Livres Públicos: Utilização de Infraestrutura Verde para Otimizar a Drenagem Urbana nos Centros Históricos Tombados

\begin{tabular}{|c|c|c|c|c|}
\hline $\begin{array}{l}\text { Praça Vidal Ramos } \\
05\end{array}$ & $\begin{array}{l}\text { Possui pares } \\
\text { de palmeiras } \\
\text { reais nos } \\
\text { quatro cantos } \\
\text { e vegetação } \\
\text { abundante } \\
\text { com variadas } \\
\text { espécies. }\end{array}$ & $\begin{array}{l}\text { Muito utilizada } \\
\text { até a década } \\
\text { de } 1990 \text { para en- } \\
\text { contro dos jovens } \\
\text { da cidade. Com } \\
\text { o fechamento do } \\
\text { cinema, perdeu } \\
\text { o movimento nos } \\
\text { finais de semana. } \\
\text { Próximo ao } \\
\text { comércio, é um } \\
\text { lugar tranquilo } \\
\text { para descanso e } \\
\text { contemplação. }\end{array}$ & $\begin{array}{l}\text { Possui um ele- } \\
\text { mento significa- } \\
\text { tivo, o chafariz } \\
\text { central, com } \\
\text { pavimentação } \\
\text { em piso hidráuli- } \\
\text { co na borda. }\end{array}$ & $\begin{array}{l}\text { Construída entre } \\
1910 \text { e } 1915 \\
\text { onde antes era } \\
\text { campo de ma- } \\
\text { nejo. É a praça } \\
\text { da igreja Matriz, } \\
\text { possuindo traça- } \\
\text { do geométrico. } \\
\text { As intervenções } \\
\text { sempre respei- } \\
\text { taram o traçado } \\
\text { inicial. } \\
\text { Representa um } \\
\text { jardim histórico. }\end{array}$ \\
\hline Rotatória & $\begin{array}{l}\text { Não possui } \\
\text { vegetação. } \\
\text { Próximo à la- } \\
\text { goa, exposta a } \\
\text { ventos fortes, } \\
\text { principalmente } \\
\text { Nordeste e } \\
\text { Sul. }\end{array}$ & $\begin{array}{l}\text { Possui um poste } \\
\text { central. Serve } \\
\text { para direcionar o } \\
\text { trânsito dos bair- } \\
\text { ros Progresso e } \\
\text { Magalhães para } \\
\text { o Centro. }\end{array}$ & $\begin{array}{l}\text { Localiza-se de } \\
\text { frente para a } \\
\text { lagoa Santo } \\
\text { Antônio dos } \\
\text { Anjos. Forma de } \\
\text { círculo. }\end{array}$ & $\begin{array}{l}\text { Não representa } \\
\text { um jardim histó- } \\
\text { rico. }\end{array}$ \\
\hline $\begin{array}{l}\text { Praça Domingos de B. } \\
\text { Peixoto }\end{array}$ & $\begin{array}{l}\text { Possui uma } \\
\text { amendoei- } \\
\text { ra; local de } \\
\text { abrigo para } \\
\text { pássaros. }\end{array}$ & $\begin{array}{l}\text { Possui dois } \\
\text { bancos. }\end{array}$ & $\begin{array}{l}\text { Localiza-se entre } \\
\text { a rotatória e } \\
\text { o cine teatro } \\
\text { Mussi. Tem um } \\
\text { monumento em } \\
\text { homenagem a } \\
\text { Domingos de } \\
\text { Brito Peixoto, } \\
\text { fundador da } \\
\text { cidade. Seu for- } \\
\text { mato constitui-se } \\
\text { como a finaliza- } \\
\text { ção da quadra. }\end{array}$ & $\begin{array}{l}\text { Tem piso de } \\
\text { ladrilho hidráu- } \\
\text { lico, o que seria } \\
\text { uma condicio- } \\
\text { nante para futura } \\
\text { intervenção. } \\
\text { Representa, em } \\
\text { parte, um jardim } \\
\text { histórico. }\end{array}$ \\
\hline Praça Paulo Carneiro & $\begin{array}{l}\text { Possui duas } \\
\text { amendoeiras, } \\
\text { próximo da } \\
\text { lagoa. }\end{array}$ & $\begin{array}{l}\text { Possui bancos, } \\
\text { lixeira e uma } \\
\text { feira itinerante de } \\
\text { produtos naturais } \\
\text { nas sextas-feiras. }\end{array}$ & $\begin{array}{l}\text { Localiza-se de } \\
\text { frente para o } \\
\text { mercado público } \\
\text { municipal. } \\
\text { Resíduo urbano } \\
\text { gerado após a } \\
\text { desativação da } \\
\text { linha férrea. }\end{array}$ & $\begin{array}{l}\text { Passou por } \\
\text { muitas interven- } \\
\text { ções; funcionava } \\
\text { antes um posto } \\
\text { de gasolina. Não } \\
\text { representa um } \\
\text { jardim histórico. }\end{array}$ \\
\hline
\end{tabular}




\begin{tabular}{|c|c|c|c|c|}
\hline $\begin{array}{l}\text { Calçadão XV de } \\
\text { Novembro }\end{array}$ & $\begin{array}{l}\text { Espaço público } \\
\text { seco, sem } \\
\text { vegetação. }\end{array}$ & $\begin{array}{l}\text { Possui bancos } \\
\text { e lixeiras pouco } \\
\text { usados. É um } \\
\text { grande corredor } \\
\text { comercial e de } \\
\text { serviços. }\end{array}$ & $\begin{array}{l}\text { Possui desenhos } \\
\text { em pedra por- } \\
\text { tuguesa no piso. } \\
\text { Rua comercial, } \\
\text { liga a praça da } \\
\text { Matriz à orla } \\
\text { da lagoa Santo } \\
\text { Antônio. }\end{array}$ & $\begin{array}{l}\text { A rua XV de } \\
\text { Novembro foi } \\
\text { palco dos ensaios } \\
\text { de carnaval da } \\
\text { cidade por muitos } \\
\text { anos. Na década } \\
\text { de } 1990 \text { foi cons- } \\
\text { truído o então } \\
\text { calçadão. Não } \\
\text { representa um } \\
\text { jardim histórico. }\end{array}$ \\
\hline Calçadão Avenida & $\begin{array}{l}\text { Espaço público } \\
\text { seco, sem } \\
\text { vegetação. Pró- } \\
\text { ximo à orla da } \\
\text { lagoa, exposto } \\
\text { a ventos. }\end{array}$ & $\begin{array}{l}\text { Possui bancos } \\
\text { quebrados e } \\
\text { serve de depósito } \\
\text { de lixo para os } \\
\text { comerciantes. }\end{array}$ & $\begin{array}{l}\text { Não possui } \\
\text { apelo estético. } \\
\text { Localiza-se em } \\
\text { frente às docas } \\
\text { da lagoa Santo } \\
\text { Antônio dos } \\
\text { Anjos. Surgiu } \\
\text { após demoli- } \\
\text { ção da antiga } \\
\text { rodoviária e um } \\
\text { antigo posto de } \\
\text { gasolina. }\end{array}$ & $\begin{array}{l}\text { Era, até o início } \\
\text { dos anos 1980, } \\
\text { local da rodoviá- } \\
\text { ria municipal. }\end{array}$ \\
\hline 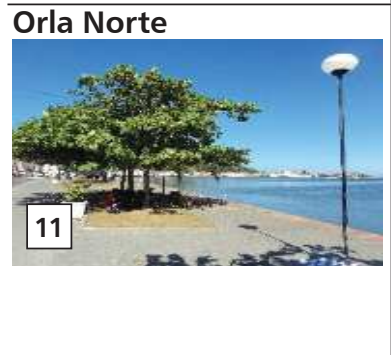 & $\begin{array}{l}\text { Possui amen- } \\
\text { doeiras e } \\
\text { pouca grama. } \\
\text { Tem um belíssi- } \\
\text { mo pôr do sol. } \\
\text { Ventos sul e } \\
\text { nordeste. }\end{array}$ & $\begin{array}{l}\text { Principais } \\
\text { usuários são } \\
\text { pescadores e } \\
\text { pessoas à espera } \\
\text { de transporte } \\
\text { público. }\end{array}$ & $\begin{array}{l}\text { Localiza-se na } \\
\text { extensão da } \\
\text { orla da lagoa } \\
\text { Santo Antônio } \\
\text { dos Anjos e é } \\
\text { dividida em } \\
\text { norte e sul pelo } \\
\text { mercado públi- } \\
\text { co municipal. }\end{array}$ & $\begin{array}{l}\text { Já passou por } \\
\text { várias interven- } \\
\text { ções. Hoje possui } \\
\text { quiosques com } \\
\text { produtos impor- } \\
\text { tados e produtos } \\
\text { naturais. Não } \\
\text { representa um } \\
\text { jardim histórico. }\end{array}$ \\
\hline Orla Sul & $\begin{array}{l}\text { Possui canteiros } \\
\text { com grama. } \\
\text { Ventos sul e } \\
\text { nordeste. }\end{array}$ & $\begin{array}{l}\text { É a doca, } \\
\text { utilizada como } \\
\text { atracadouro } \\
\text { para pequenas } \\
\text { embarcações. }\end{array}$ & $\begin{array}{l}\text { Representa a } \\
\text { orla da parte } \\
\text { sul do mercado } \\
\text { público. Possui } \\
\text { um monumento } \\
\text { do Rotary Clube } \\
\text { de Laguna. }\end{array}$ & $\begin{array}{l}\text { Passou por várias } \\
\text { intervenções. Já } \\
\text { teve alguns tipos } \\
\text { de bancas de pei- } \\
\text { xe, hoje extintas. } \\
\text { Não representa } \\
\text { um jardim histó- } \\
\text { rico. }\end{array}$ \\
\hline
\end{tabular}

Quadro produzido por Claudione Medeiros (2015) para análise dos espaços livres públicos de Laguna (SC). Fotos de Claudione Medeiros e análise da concepção cultural/histórica baseada nos estudos de Morais (2016).

A partir das análises apresentadas no quadro, e como forma de comprovar a aplicabilidade da infraestrutura verde nos espaços livres públicos do centro de Laguna, foi elaborado um mapa de aplicação do conceito de infraestrutura verde (figura 16) e algumas imagens esquemáticas relacionadas a ele nas figuras 17 a 28 . Foi incorporado nesses desenhos o conceito de infraestrutura verde para otimizar a drenagem urbana e evitar alagamentos pontuais, principalmente próximo ao casario tombado. $\bigcirc$ mapa abaixo foi estruturado em quatro eixos: três possuem um espaço livre estruturador e coincidem com os principais talvegues formados dentro da microbacia do centro de Laguna; o quarto eixo é o receptor das águas, localizado na orla da lagoa. 


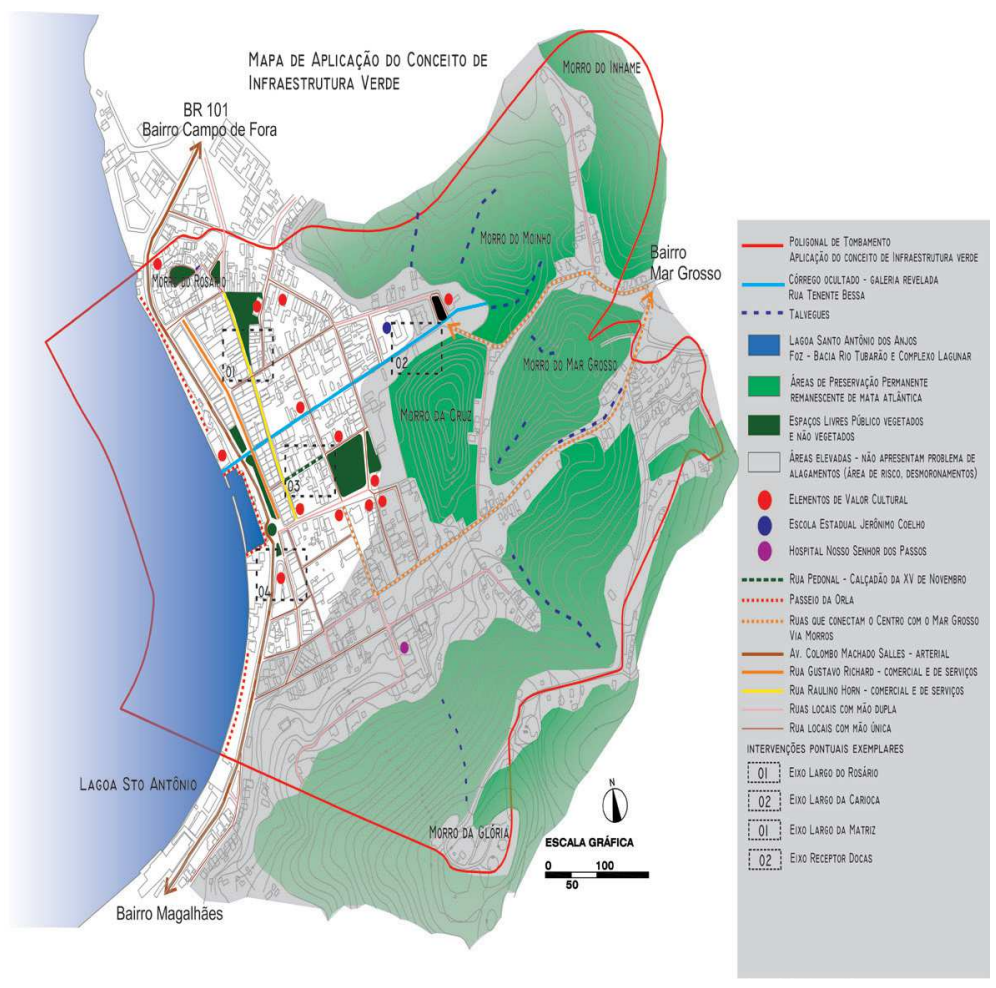

Poligonal de Tombamento

APLICAÇÃO DO CONCEITO DE INFRAESTRUTURA VERDE CóRREgo OCULTADO - GALERIA REVELADA

RUA TENENTE BESSA

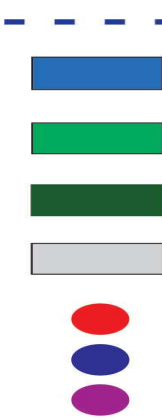

TALVEGUES

LAGOA SANTO ANTONNIO DOS ANJOS

FOZ - BACIA RIO TUBARÃo E COMPLEXO LAGUNAR

Áreas de PRESERVAÇÃo PERMANENTE REMANESCENTE DE MATA ATLÂNTICA

ESPAÇOS LIVRES PÚBLICO VEGETADOS E NÃO VEGETADOS

ÁreAs elevadAs - NÃo APRESENTAM PROBLEMA DE ALAGAMENTOS (ÁREA DE RISCO, DESMORONAMENTOS) ELEMENTOS DE VALOR CULTURAL

ESCOLA ESTADUAL JERÔNIMO COELHO

HOSPITAL NOSSO SENHOR DOS PASSOS

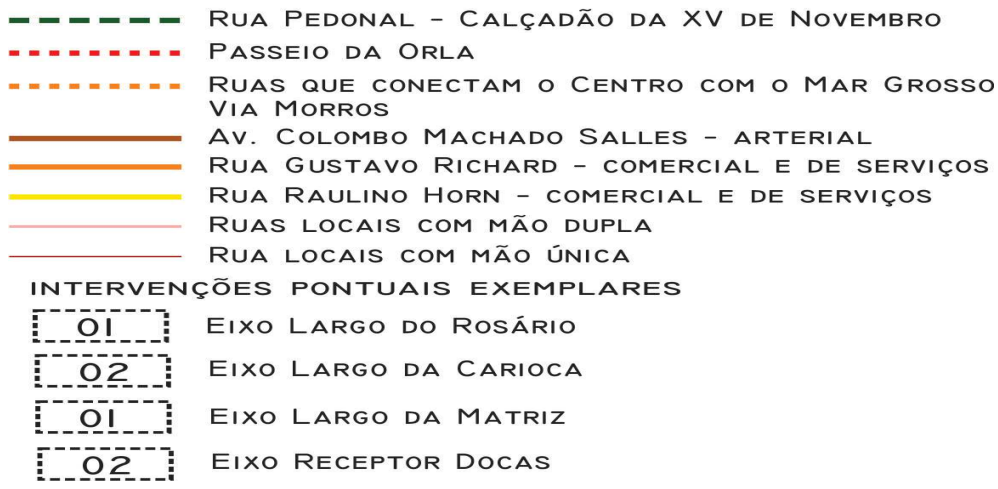

Figura 16 Mapa de aplicação do conceito de infraestrutura verde. Fonte: Mapa produzido em 2015 por Claudione Medeiros, utilizando a base cartográfica do Escritório Técnico do Iphan de Laguna (SC). 
O eixo largo do Rosário (figura 17) possui como elemento estruturador o morro do Rosário e a praça República Juliana. Nesta são realizadas homenagens cívicas e eventos culturais, portanto as intervenções precisam respeitar essa vocação do local. São inseridos os jardins de chuvas, canteiros pluviais e uma cisterna - que coleta água do telhado do museu Anita Garibaldi para ser utilizada na manutenção da praça (figura 18). Os pontos com maior alagamento estão no sopé do morro, onde foi inserido um jardim de chuvas para auxiliar na drenagem tradicional existente. Os canteiros pluviais auxiliam na absorção das águas das chuvas que se acumulam entre a via de rolamento e as guias, deixando livre o caminho para pedestres (figura 19).

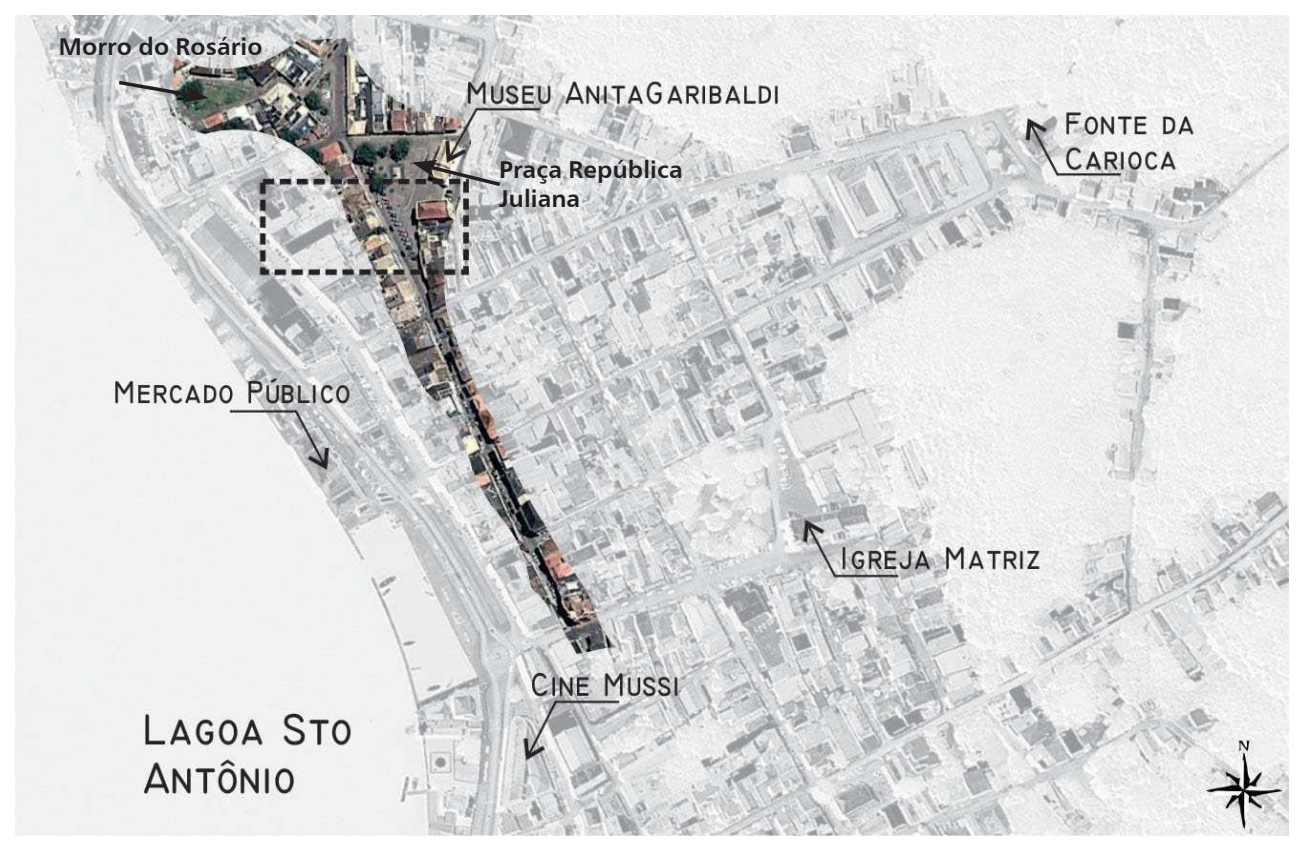

Figura17 Imagem de localização do eixo largo do Rosário.

Fonte: Figura adaptada sobre imagem do Google Earth, 2015, por Claudione Medeiros, 2015.

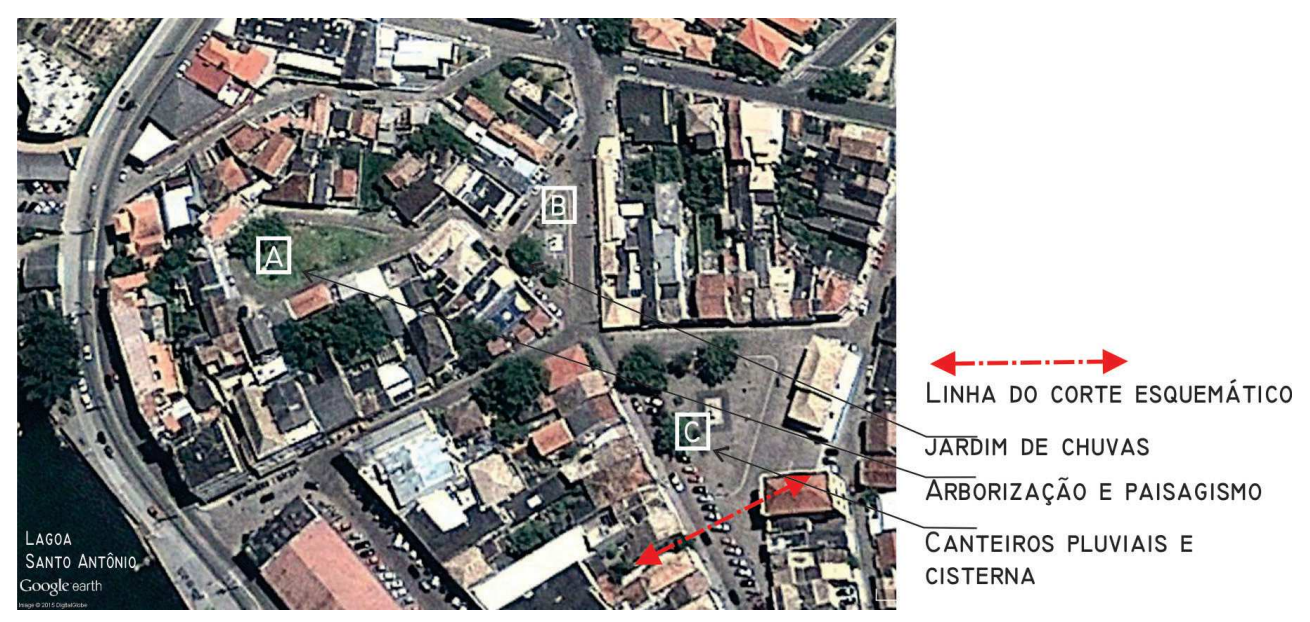

Figura1 8 Intervenções pontuais exemplares no eixo largo do Rosário.

Fonte: Produzida por Claudione Medeiros, 2015, sobre imagem do Google Earth, 2015. 


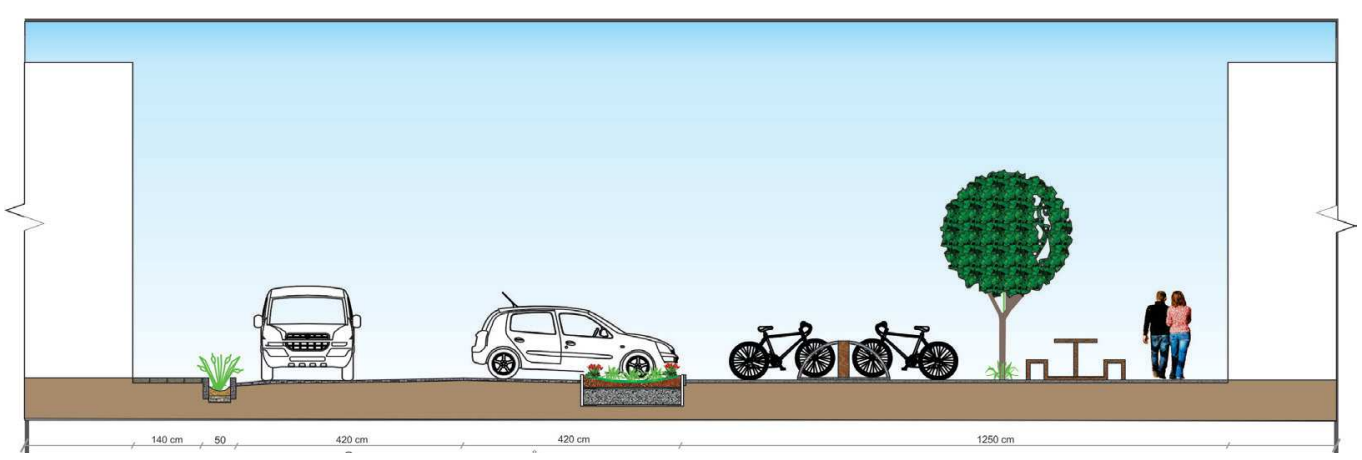

Figura 19 Corte esquemático do eixo largo do Rosário.

Fonte: Claudione Medeiros, 2015.

O segundo eixo é o largo da Carioca, que representa o principal talvegue identificado nas análises dos mapas (figura 20); a praça Lauro Muller e a fonte da Carioca são os espaços livres estruturadores desse eixo. Evidências explícitas da existência de um córrego na área em questão são encontradas na descrição da cidade em 1880, feita por Ulysséa (1943). O córrego foi canalizado em 1911 devido à construção do colégio Jerônimo Coelho. Sendo assim, a proposta dessa aplicação de infraestrutura verde é retomar esse caminho natural das águas através de vala britada e um sistema de calhas ou biovaletas conectando o jardim de chuvas e os canteiros pluviais (figuras 21 e 22). O parque infantil, inserido no eixo, representa novas possibilidades de uso e permanência no espaço livre reabilitado, protegido dos ventos, localizado na travessa Clito Araúio, vizinho ao colégio Jerônimo Coelho.

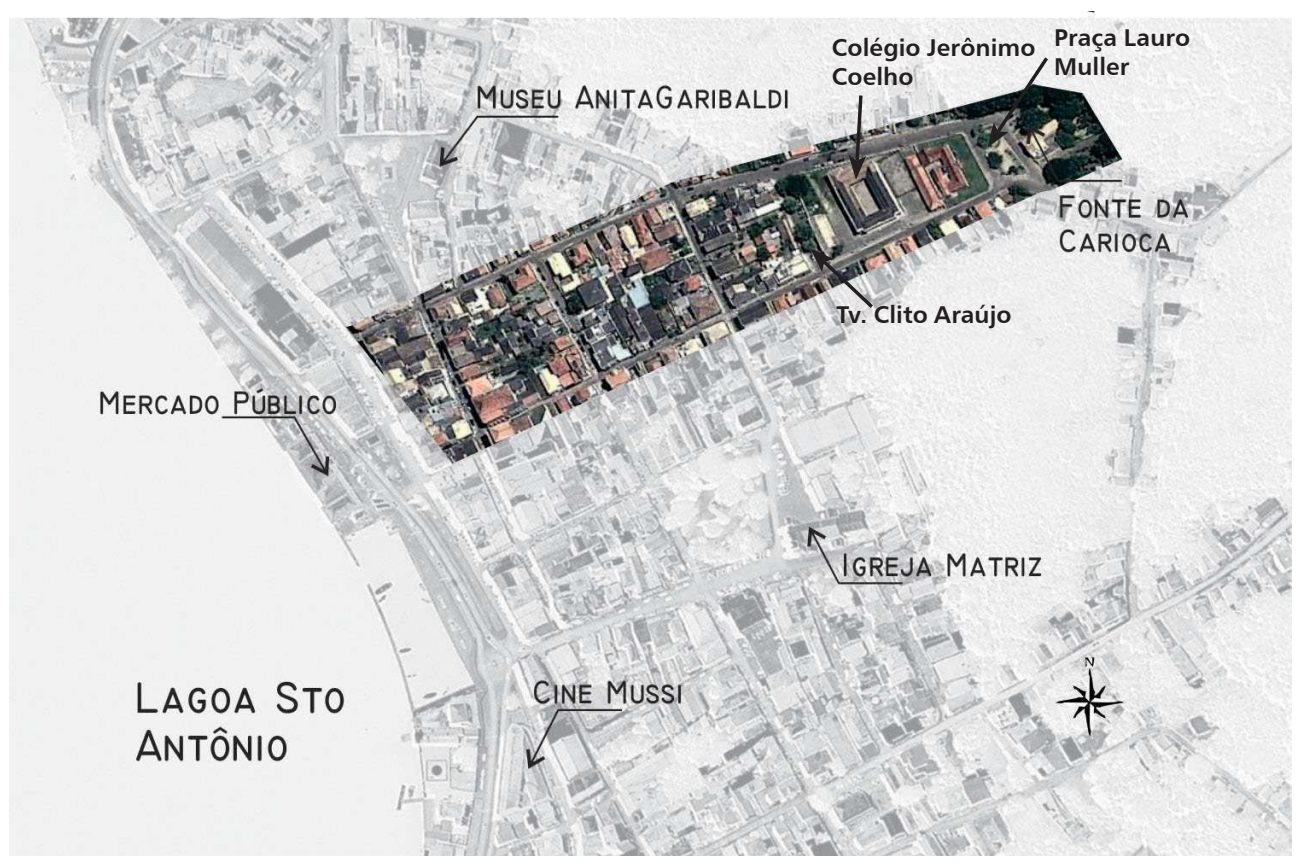

Figura 20 Mapa de aplicação de localização do eixo largo da Carioca.

Fonte: Figura adaptada sobre imagem do Google Earth, 2015, por Claudione Medeiros, 2015. 


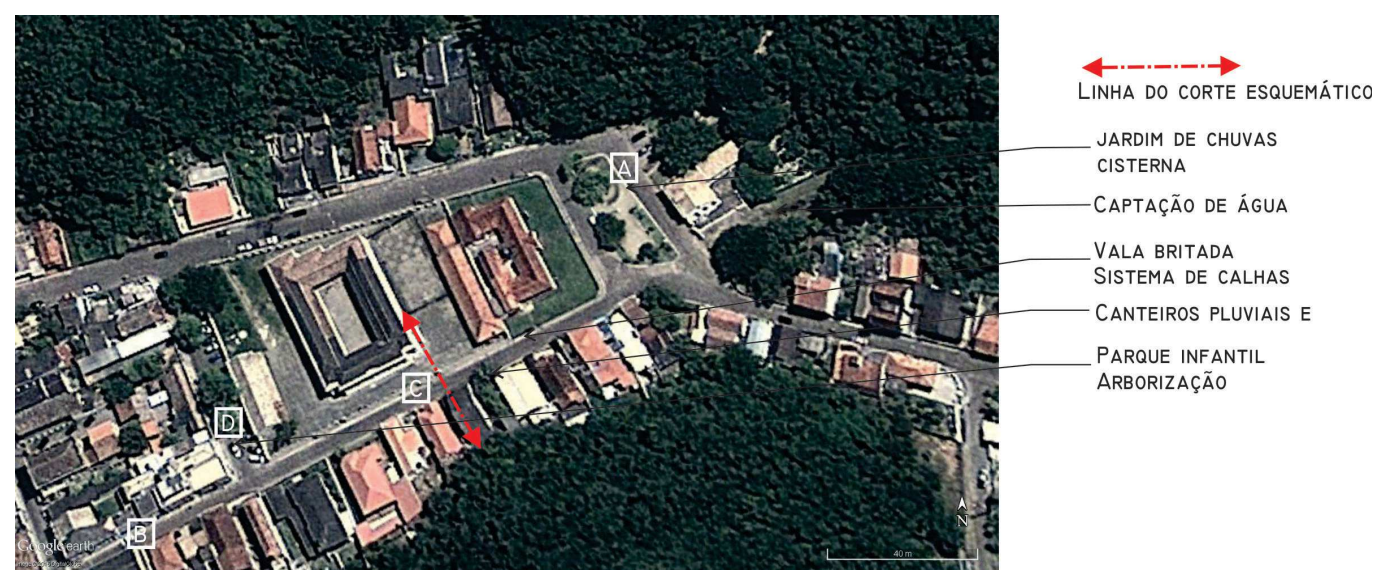

Figura 21 Intervenções pontuais exemplares no eixo largo da Carioca.

Fonte: Figura adaptada sobre imagem do Google Earth, 2015, por Claudione Medeiros, 2015.

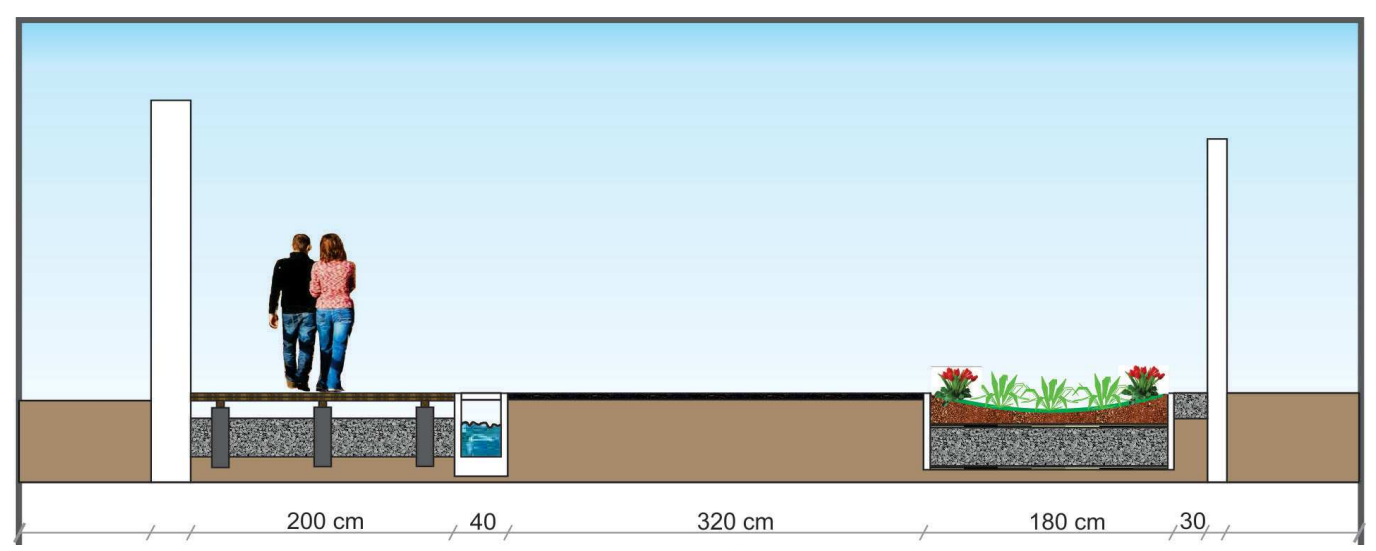

Figura 22 Corte esquemático do eixo largo da Carioca. Fonte: Claudione Medeiros, 2015.

O eixo Largo da Matriz é formado pela praça Vidal Ramos e pelas ruas que a ligam à lagoa Santo Antônio dos Anjos (figura 23). A rua com maior índice de alagamentos é a XV de Novembro. Utilizada como calçadão, receberá canteiros pluviais para afastar as águas de chuva do casario e permitir a passagem de pedestres (figura 24 e 25). O sistema de calhas e valas britadas também servirá para potencializar, além do direcionamento das águas para a lagoa, a capacidade de percolação. A praça estruturante desse eixo é identificada como jardim histórico; nesse caso, as intervenções devem respeitar as diretrizes e legislação pertinentes. Por fazer parte desse contexto vários prédios públicos, como o centro cultural, a matriz e o conservatório de música, a cisterna receberá a captação das águas de chuva dos telhados dos edifícios e servirá para manutenção da praça e recurso para o chafariz central. 
Espaços Livres Públicos: Utilização de Infraestrutura Verde para Otimizar a Drenagem Urbana nos Centros Históricos Tombados

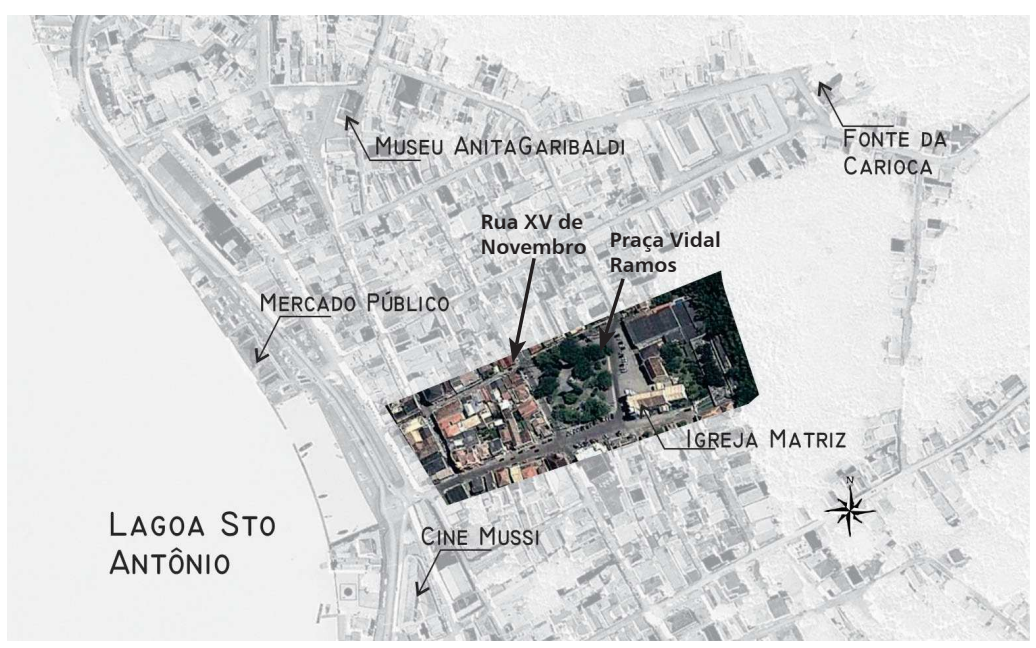

Figura 23 Mapa de aplicação de localização do eixo largo da Matriz.

Fonte: Figura adaptada sobre imagem do Google Earth, 2015, por Claudione Medeiros, 2015.

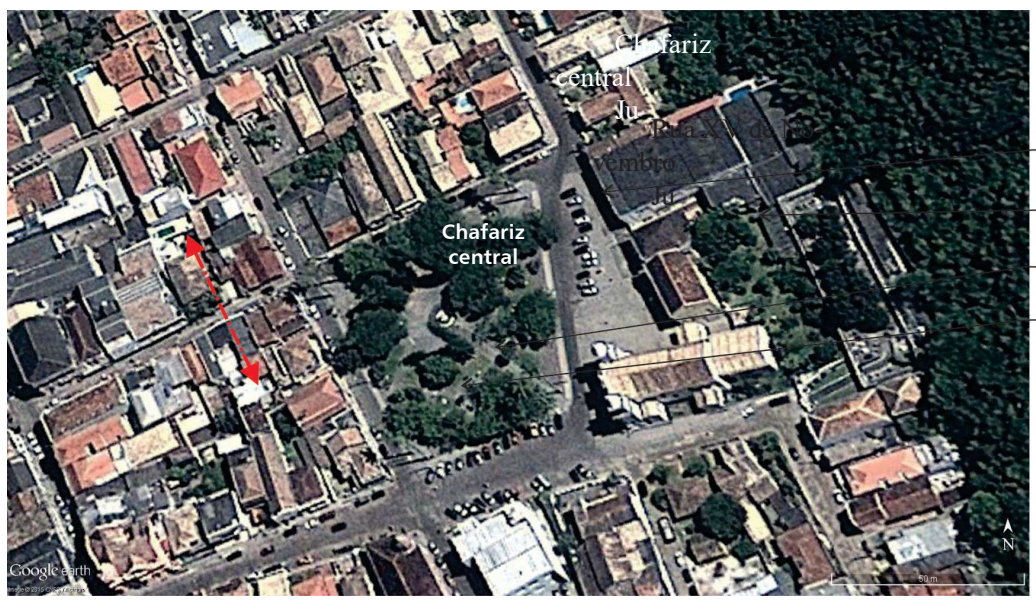

LINHA DO CORTE ESQUEMÁTICO

JARDIM DE CHUVAS CISTERNA

CAPTAÇÃO de ÁGUA

VALA BRITADA

SISTEMA DE CALHAS

CANTEIROS PLUVIAIS

Figura 24 Intervenções pontuais exemplares no eixo largo da Matriz.

Fonte: Figura adaptada sobre imagem do Google Earth, 2015, por Claudione Medeiros, 2015.

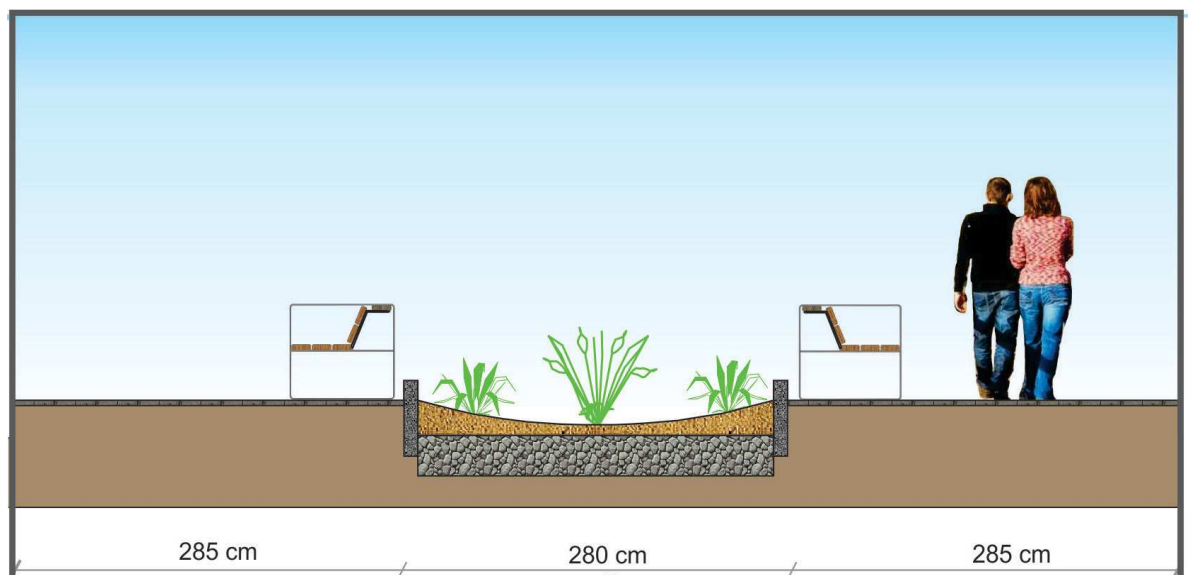

Figura 25 Corte esquemático do eixo largo da Matriz.

Fonte: Medeiros (2015). 
O quarto eixo, aqui denominado eixo Receptor Docas, é formado pela extensão da orla da lagoa Santo Antônio dos Anjos no Centro (figura 26). É o principal eixo formador da infraestrutura proposta, pois é o destino dos demais. Para ele é proposta uma ciclovia a fim de aumentar a mobilidade urbana na avenida Colombo Machado Salles, que corta o Centro ligando-o aos demais bairros da cidade (figuras 27 e 28). Em toda a extensão desse eixo receptor foram detectados problemas de alagamento, embora a lagoa esteja a poucos metros. $\bigcirc$ sistema de infraestrutura verde conectará os outros eixos até o corpo hídrico e aumentará a capacidade de absorção das águas de chuva.

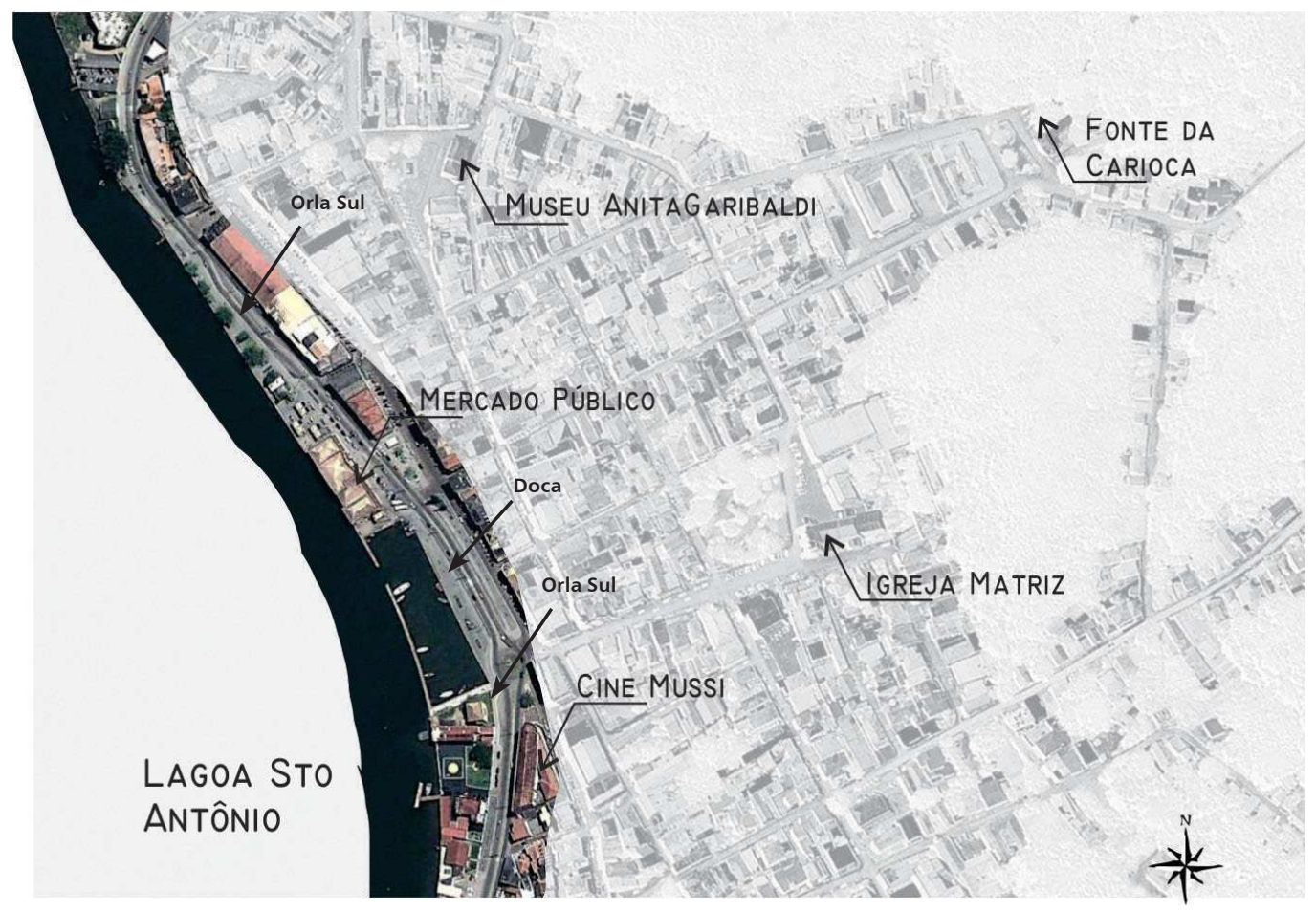

Figura 26 Mapa de aplicação de localização do eixo Receptor Docas.

Fonte: Adaptada sobre imagem do Google Earth, 2015, por Medeiros (2015).

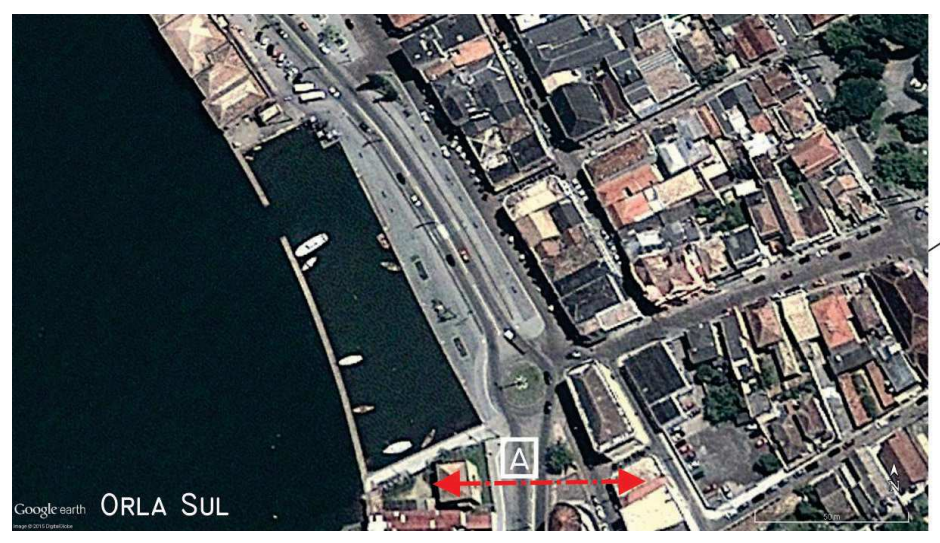

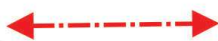

LINHA DO CORTE ESQUEMÁTICO

ABRIGO DE ÔNIBUS COM TETOVERDE

CICLOVIA

CANTEIROS PLUVIAIS

SISTEMA DE CALHAS

Figura 27 Intervenções pontuais exemplares no eixo Recptor Docas.

Fonte: Figura adaptada sobre imagem do Google Earth, 2015, por Claudione Medeiros, 2015. 


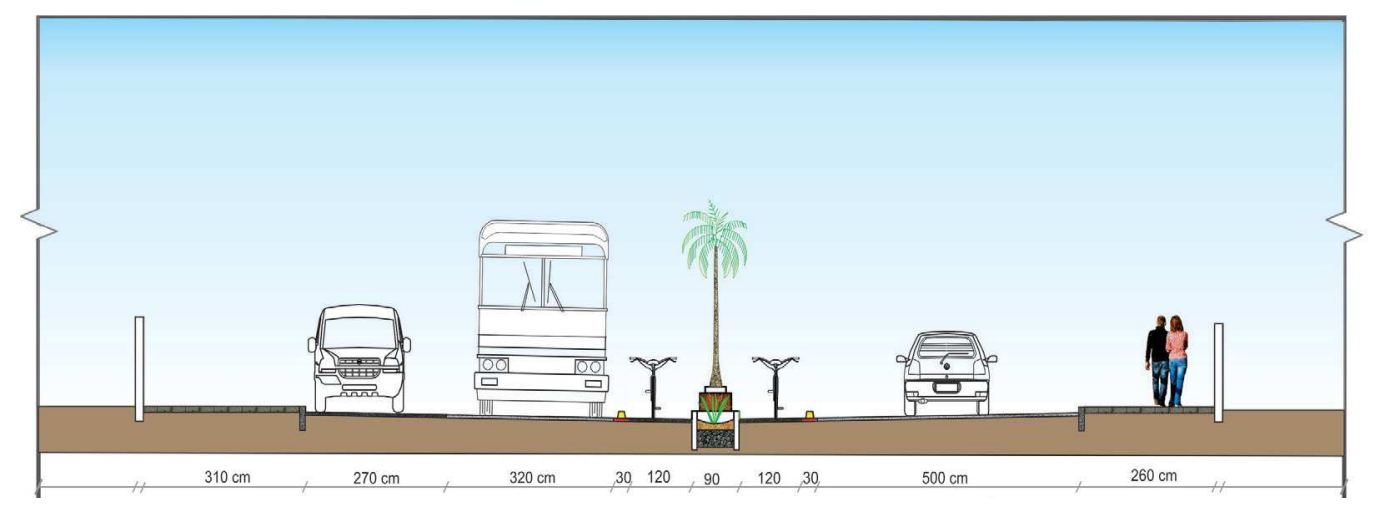

Figura 28 Corte esquemático do eixo Receptor Docas. Fonte: Claudione Medeiros, 2015.

\section{CONSIDERAÇÕES FINAIS}

Os centros históricos tombados necessitam de técnicas que promovam o seu desenvolvimento por meio de estratégias de baixo impacto, haja vista sua situação já consolidada e a existência de uma paisagem cultural marcante, com casario e arruamentos. A ineficiência dos sistemas de drenagem tradicionais e os danos causados ao patrimônio devido a mudanças climáticas são evidentes.

A infraestrutura verde pode contribuir consideravelmente para promover a revitalização desses centros, valorizando sua paisagem e aumentando a eficácia da drenagem urbana por ser um sistema que se aproveita dos espaços livres públicos existentes - cuja forma é flexível e resgata as funções inerentes ao sítio sem impactar ou desconsiderar a forma urbana preexistente.

As consequências da utilização de infraestrutura verde serão a valorização paisagística do Centro e as possibilidades de permanência nessa área, além do principal benefício, que, diminuindo a vazão das enxurradas e aumentando a infiltração das águas de chuva vai proteger os patrimônios construído e natural. O paisagismo agrega valores e sensações que atraem as pessoas, tornando mais seguro e aconchegante $\circ$ lugar público e melhorando a qualidade de vida da população.

O planejamento urbano deve procurar tornar as cidades resilientes em face das mudanças climáticas, com capacidade de resposta e recuperação aos eventos de chuvas intensas, cada vez mais frequentes. Essa busca pelo equilíbrio entre o construído e o natural soma-se aos anseios de preservação do patrimônio consolidado, prerrogativas do Iphan para a implementação de ações que preservem os bens tombados, transformando os centros das cidades em locais acessíveis, com diversidade social e funcional e geradores do fortalecimento da identidade cultural.

A identificação dos espaços livres públicos passíveis da aplicação da infraestrutura verde no centro histórico tombado de Laguna apontou apenas a praça Vidal Ramos como exemplo de jardim histórico, pois possui características de composição arquitetônica e vegetal que devem ser preservadas do ponto de vista histórico. Tal espaço, 
analisado de acordo com as recomendações da Carta de Florença de 1981 (CURY, 2004), é passível de restauração, manutenção e conservação, no entanto, qualquer modificação precisará ser justificada e aprovada pelos órgãos competentes, respeitando a evolução do jardim e cada época desde sua criação.

Os demais espaços identificados como passíveis de receber infraestrutura verde poderão aumentar e potencializar as áreas permeáveis e promover o equilíbrio do ciclo hidrológico das águas, aumentando a infiltração, a percolação e a evapotranspiração. A locação dessas estratégias ecológicas deverá coincidir com os principais pontos de alagamento, observados em campo após chuvas intensas e enxurradas.

Estudar os espaços livres públicos dos centros históricos tombados é apenas o ponto de partida para futuros projetos de revitalização utilizando a infraestrutura verde. Difundir tais estratégias e promover a globalização desse conhecimento - unindo estudos científicos com aplicações existentes em outros países - motivará a criação de um modelo sustentável e maleável para cidades tombadas. Os estudos científicos devem contribuir para a constituição do planejamento urbano por meio de ações e diretrizes produzidas por equipes interdisciplinares, formadas para explorar os métodos e estratégias de infraestrutura verde. Esta se apresenta não só como opção paisagística, mas como resiliência urbana, amenizando os riscos aos quais as cidades estão cada vez mais expostas.

\section{REFERÊNCIAS BIBLIOGRÁFICAS}

AB'SABER, Aziz Nacib. Os domínios de natureza no Brasil: potencialidades paisagísticas. São Paulo: Ateliê Editorial, 2003. Disponível em: <http://pt.scribd.com/doc/94538576/AB-SABER-Aziz-Nacib-Os-dominios-denatureza-no-Brasil-potencialidades-paisagisticas >. Acesso em: 13 set. 2014.

ANDRADE, Rodrigo Melo Franco de. Rodrigo e o Sphan: coletânea de textos sobre o patrimônio cultural. Rio de Janeiro: Ministério da Cultura, Fundação Nacional Pró-Memória, 1987.

ARAÚJO, Guilherme Maciel. Paisagem cultural: um conceito inovador. In: CASTRIOTA, Leonardo Baci (Org.). Paisagem cultural e sustentabilidade. Belo Horizonte: IEDS; UFMG, 2009, pp. 25-45. Disponível em: <http://iscte- iul.academia.edu/TeresaMaratMendes/Books / 1 17100/Paisagem_Cultural_e_Sustentabilidade > . Acesso em: 3 mar. 2014

BALTAZAR, A. P. Sobre a resiliência dos sistemas urbanos: devem eles ser resilientes e são eles realmente sistemas? In: V!RUS, n. 3. Tradução de Biaggioni, B. e D’Andréa, A. São Carlos: Nomads.usp, 2010. Disponível em: <http://www.nomads.usp.br/virus/virus03/invited/layout.php? item=1\&lang=pt>. Acesso em: 4 set. 2014.

BOCCHINI, Bruno. Dois anos após inundação, São Luiz do Paraitinga está $80 \%$ reconstruída. Jornal Notícia na Hora, 2012. Disponível em: <http://www.noticianahora.com.br/brasil/noticia/dois-anos-apos-inundacao-sao-luizdo-paraitinga-esta-80-reconstruida/103649>. Acesso em: 6 ago. 2017.

BRASIL. Ministério das Cidades. Instituto do Patrimônio Histórico e Artístico Nacional. Implementação de ações em áreas urbanas centrais e cidades históricas: manual de orientação. Brasília/DF: Iphan: Ministério das Cidades, 2011.

BUENO, Eduardo Silva; XIMENES, Deize Sbarai Sanches. A importância da infraestrutura verde no desenho ambiental: estudo da área da Cidade Universitária e Instituto Butantã. LABVERDE. São Paulo: FAUUSP, v. 3, 2011. Disponível em: <http://www.revistas.usp.br/revistalabverde/article/view/61420/64332>. Acesso em: 4 set. 2014.

CASTRIOTA, Leonardo Barci Castriota. Patrimônio cultural: conceitos, políticas, instrumentos. Belo Horizonte: Instituto de Estudo do Desenvolvimento Sustentável, 2009.

CORMIER, Nathaniel S.; PELLEGRINO, Paulo Renato Mesquita. Infraestrutura verde: uma estratégia paisagística para a água urbana. Paisagem e Ambiente: ensaios. São Paulo: FAUUSP, n. 25, 2008, pp. 127-142. 
Espaços Livres Públicos: Utilização de Infraestrutura Verde para Otimizar a Drenagem Urbana nos Centros Históricos Tombados

CURY, Isabelle (Org.). Cartas Patrimoniais. 3 ed. rev. e aum. Rio de Janeiro: Iphan, 2004.

EPAGRI. Empresa de Pesquisa Agropecuária e Extensão Rural de Santa Catarina. As chuvas de novembro de 2008 em Santa Catarina. Disponível em: <http://intranetdoc.epagri.sc.gov.br/producao tecnico cientifica/ DOC_3661.pdf>. Acesso em: 22 ago. 2014.

GOOGLE. Google Earth website. Disponível em: <http://earth.google.com/>. Acesso em: set. 2015.

HERZOG, Cecília Polacow. Infraestrutura verde para cidades mais sustentáveis. Secretaria do Ambiente. Versão Executiva. [S. I.]: ICLEl Brasil, 2010.

IPHAN. Patrimônio mundial: fundamentos para seu reconhecimento. Brasília, DF: Iphan, 2008. Disponível em: <http://portal.iphan.gov.br/files/Cartilha_do_Patrimonio_Mundial.pdf>. Acesso em 13 set. 2014.

LIMBERGER, Lucienne Rossi Lopes; SANTOS, Nara Rejane Zamberlan. Caderno Didático Paisagismo 1. Santa Maria: Universidade Federal de Santa Maria, março, 2000.

MACEDO, Silvio Soares. Paisagem, urbanização e litoral: do éden à cidade. 1993. 207 f. Tese (Livre-Docência) - Faculdade de Arquitetura e Urbanismo da Universidade de São Paulo, São Paulo, 1993.

MAGALHÃES, Manuela Raposo. A arquitectura paisagista: morfologia e complexidade. Lisboa: Estampa, 2001.

MEDEIROS, Claudione Fernandes de. Paisagem e drenagem urbana: estratégias de infraestrutura verde para a revitalização do centro histórico de Laguna/SC. 2015. 228 f. Dissertação (Mestrado em Arquitetura e Urbanismo) Curso de Arquitetura e Urbanismo da Universidade Federal de Santa Catarina, Florianópolis, 2015.

MORAIS, Diego Steffen. Revitalização urbana de Laguna. Laguna, Iphan, 2006. CD-ROM.

PELLEGRINO, Paulo Renato M. A paisagem como infraestrutura: função e método. Volume apresentado ao concurso de títulos da Faculdade de Arquitetura e Urbanismo da Universidade de São Paulo (FAUUSP). São Paulo: Universidade de São Paulo, 2014. CD-ROM.

RIBEIRO, Rafael Winter. Paisagem cultural e patrimônio. Rio de Janeiro: Iphan; Copedoc, 2007.

SOUZA, Marco Aurélio. Chuva provoca destruição em Laguna. Jornal de Laguna, p. 3, 21 set. 2004.

ULYSSÉA, Saul. A Laguna de 1880. Florianópolis: IOFSC, 1943.

UNESCO. United Nations Educational, Scientific and Cultural Organization. Orientações técnicas para aplicação da Convenção do Patrimônio Mundial. Lisboa, 2010. Disponível em: < http://whc.unesco.org/archive/ opguide 1 1-pt.doc >. Acesso em: 15 jul. 2015.

WATERMAN, Tim. Fundamentos de paisagismo. Porto Alegre: Bookman, 2010. 